\title{
Comparative proteomics analysis of proteins expressed in the I-1 and I-2 internodes of strawberry stolons
}

\author{
Xianping Fang ${ }^{1}$, Huasheng Ma*, Dezhao Lu², Hong Yu', Wenguo Lai ${ }^{1}$ and Songlin Ruan ${ }^{1 *}$
}

\begin{abstract}
Background: Strawberries (Fragaria ananassa) reproduce asexually through stolons, which have strong tendencies to form adventitious roots at their second node. Understanding how the development of the proximal $(I-1)$ and distal (I-2) internodes of stolons differ should facilitate nursery cultivation of strawberries.

Results: Herein, we compared the proteomic profiles of the strawberry stolon I-1 and I-2 internodes. Proteins extracted from the internodes were separated by two-dimensional gel electrophoresis, and 164 l-1 protein spots and $200 \mathrm{I}-2$ protein spots were examined further. Using mass spectrometry and database searches, $38 \mathrm{I}-1$ and 52 I-2 proteins were identified and categorized ( 8 and 10 groups, respectively) according to their cellular compartmentalization and functionality. Many of the identified proteins are enzymes necessary for carbohydrate metabolism and photosynthesis. Furthermore, identification of proteins that interact revealed that many of the I-2 proteins form a dynamic network during development. Finally, given our results, we present a mechanistic scheme for adventitious root formation of new clonal plants at the second node.
\end{abstract}

Conclusions: Comparative proteomic analysis of $\mathrm{I}-1$ and $\mathrm{I}-2$ proteins revealed that the ubiquitin-proteasome pathway and sugar-hormone pathways might be important during adventitious root formation at the second node of new clonal plants.

\section{Background}

Several stoloniferous species produce long, sympodial stolons with rooted rosettes (ramets) at their nodes $[1,2]$. For the garden strawberry (Fragaria ananassa), the mother plant forms plantlets on stolons during spring growth (Figure 1). The first stolon originates from an auxiliary leaf bud produced in the central crown and commonly contains only two nodes. The regions along the stolon and between the plant and the first node and the first and second nodes are the I-1 (proximal) and I-2 (distal) internodes, respectively. Although stolon growth requires internode elongation, the fates of the two nodes are dissimilar. First, I-1 elongates and terminates at the first node, which is nonproductive, then I-2 elongates and terminates at the second node, which forms the main crown of the clonal plant.

\footnotetext{
* Correspondence: hzhsma@163.com; ruansl1@hotmail.com 'Laboratory of Plant Molecular Biology and Proteomics, Institute of Biology, Hangzhou Academy of Agricultural Sciences, Hangzhou 310024, China Full list of author information is available at the end of the article
}

Many studies have assessed the relationships between plant genotype and phenotype [3] using morphological differences caused by loss of function or altered expression of a single gene. To fully understand the function of a gene, however, the expressed protein must be characterized. Proteomics investigates the synthesis, turnover, and modification of proteins so that gene function and genotypes can be understood [4]. For example, a proteomic study of ripening strawberry fruit from plants of different genotypes identified constitutively and differentially expressed proteins that probably control the quality of the fruit [5]. Proteomics may, therefore, be used to address biochemical and physiological aspects of plant morphologies. Such approaches are increasingly used to elucidate the biochemistry and physiology of model species [6,7]. Yet proteomics is limited by the ability to identify proteins, which relies on the availability of sequence data. For plant species with unsequenced genomes, proteomics can still be applied but the number of identified proteins is usually smaller because their
Ciomed Central

(c) 2011 Fang et al; licensee BioMed Central Ltd. This is an Open Access article distributed under the terms of the Creative Commons Attribution License (http://creativecommons.org/licenses/by/2.0), which permits unrestricted use, distribution, and reproduction in any medium, provided the original work is properly cited. 


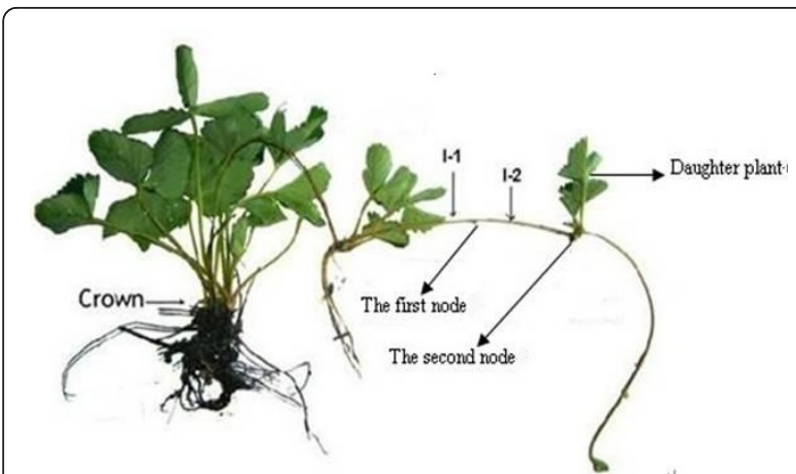

Figure 1 The strawberry stolon. As shown, a stolon shoots away from the base of a strawberry plant. A clone is formed at a variable distance away from the parent at the second node concomitant with adventitious root formation.

identification relies on homology with proteins of other species. For example, although $F$. ananassa sequence data is very limited, two proteomic techniques, namely two-dimensional gel electrophoresis (2-DE) and mass spectrometry (MS), have been used to identify an $F$. ananassa protein homologous to the birch pollen allergen Bet v 1 [8].

Elongation of the strawberry stolon is considered to be the result of cell division and cell expansion [9], but little is known about how the I-1 and I-2 internodes develop. Such knowledge is required, however, if we are to improve the cultivation of nursery strawberries and understand in greater depth how clonal multiplication occurs.

For the work reported herein, we compared the proteomes of the $F$. ananassa I- 1 and I-2 internodes to elucidate the differences in their growth and functional characteristics and establish reference maps by identifying the protein spots of their 2-DE maps in conjunction with MS peptide mass determination and database searches. We identified isoforms of several proteins and present a detailed analysis of the two proteomes, which allows us to begin to explore the different developmental mechanisms of the I-1 and I-2 internodes. The reference maps should be useful for investigation of strawberry physiology and for monitoring changes in protein expression in strawberry stolons in response to biotic and abiotic stresses.

\section{Materials and methods Plant material}

The F. ananassa cultivar Hongjia was obtained from a nursery at the Hangzhou Academy of Agricultural Sciences, Zhejiang, China. The plants were grown in a tunnel greenhouse with a 10-h light/14-h dark cycle, a $30^{\circ} \mathrm{C}$-day $/ 26^{\circ} \mathrm{C}$-night temperature cycle, $150 \mu \mathrm{mol} \mathrm{m}{ }^{-2} \mathrm{~s}^{-1}$ light intensity, and a relative humidity of $60 \%$. Plants were watered regularly and provided adequate nutrients. In the morning, after transplantation, stolons that had formed from the leaf buds of three-month-old plants were collected and cut to isolate the I-1 and I-2 internodes (Figure 1). Daughter plants that had formed at the apices of stolons had not been allowed to root. For each experiment, 50 stolons were randomly chosen and removed from four or five plants. The I-1 and the I-2 internodes were pooled separately, rinsed with water to remove contaminants, quickly dried with paper towels, frozen in liquid nitrogen, and stored at $-80^{\circ} \mathrm{C}$ prior to protein extraction.

\section{Protein extraction}

Proteins were extracted using acetone and trichloroacetic acid method. A portion ( $2 \mathrm{~g}$ ) of each internode sample was pulverized with a pestle in a mortar that contained liquid nitrogen and then homogenized in $10 \mathrm{~mL}$ of $10 \%$ $(\mathrm{w} / \mathrm{v})$ trichloroacetic acid, $0.07 \%(\mathrm{v} / \mathrm{v}) 2$-sulfanylethanol in acetone. Total protein was precipitated for $1 \mathrm{~h}$ or overnight at $-20^{\circ} \mathrm{C}$. The extracts were each centrifuged at $13000 \times g$ for $20 \mathrm{~min}$ at $4^{\circ} \mathrm{C}$. The pellets were washed three times with $0.07 \%(\mathrm{v} / \mathrm{v}) 2$-sulfanylethanol in acetone, and vacuum dried for $30 \mathrm{~min}$. The dried powders (30 mg) were each resuspended in $500 \mu \mathrm{L}$ of $7 \mathrm{M}$ urea, $2 \mathrm{M}$ thiourea, 4\% 3-[(3-cholamidopropyl) dimethylammonio]-1-propanesulfonate (CHAPS), 0.75\% dithiothreitol (DTT), 0.5\% Biolyte (pH 3.0-10.0, Bio-Rad), 1 mM phenylmethanesulfonyl fluoride, and then shaken vigorously for $1 \mathrm{~h}$ at room temperature. Insoluble material was removed by centrifugation at $13000 \times g$ for $15 \mathrm{~min}$ at $20^{\circ} \mathrm{C}$. At least three replicates were prepared. Protein concentrations were determined using Bio-Rad Protein Assay kit reagents (standard Bradford method) with bovine serum albumin as the calibration standard [10].

\section{Two-dimensional gel electrophoresis}

Each sample contained $300 \mu \mathrm{g}$ protein in $350 \mu \mathrm{L}$ of $8 \mathrm{M}$ urea, $2 \mathrm{M}$ thiourea, 2\% CHAPS, 0.5\% Biolyte (pH 3-10), 0.75\% M DTT, 0.002\% Bromophenol Blue. Each sample was each loaded onto a $17-\mathrm{cm}$ immobilized $\mathrm{pH}$ (3-10) gradient strip (Bio-Rad). The strips were rehydrated for $12 \mathrm{~h}$ at $50 \mathrm{~V}$. Isoelectric focusing used a linear ramp from 0 to $250 \mathrm{~V}$ in $15 \mathrm{~min}$, a linear ramp from 250 to $10000 \mathrm{~V}$ in $1 \mathrm{~h}$, and $10000 \mathrm{~V}$ for $5 \mathrm{~h}$, all at $20^{\circ} \mathrm{C}$. After isoelectric focusing, the strips were equilibrated in $50 \mathrm{mM}$ Tris- $\mathrm{HCl}, \mathrm{pH} 8.8,6 \mathrm{M}$ urea, 20\% glycerol, 2\% sodium dodecyl sulfate (SDS), $2 \%$ DTT, and then in a solution of the same composition that also contained $2.5 \%(\mathrm{w} / \mathrm{v})$ iodoacetamide, (the time of each incubation was $15 \mathrm{~min})$. The strips were then each placed onto a 1-mm-thick SDS $(12.5 \%(\mathrm{w} / \mathrm{v}))$ polyacrylamide gel and sealed with $1 \%(\mathrm{w} / \mathrm{v})$ agarose. Electrophoresis was carried out in a Bio-Rad PROTEAN apparatus at 
$24 \mathrm{~mA} /$ gel. The gels were stained using a modified silver-staining method that is compatible with MS [11]. Image analysis was subsequently performed. These procedures were replicated three times.

\section{Image acquisition and analysis}

The three replicates of the I-1 and I-2 2-DE gels were scanned using a calibrated densitometer (GS-800, BioRad), and the spot patterns were characterized using PDQuest software (ver. 8.0.1, Bio-Rad). Image analysis steps included image filtration, spot detection and measurement, background subtraction, and spot matching. One I-1 gel served as the reference, and the spots of the other five gels were referenced to it. Initially, spots were automatically matched, and the positions of unmatched spots were then manually determined. The molecular mass $(\mathrm{kDa})$ of each protein was estimated by comparison with those of a standard marker set, and the isoelectric points (pIs) were determined by the spot positions along the immobilized $\mathrm{pH}$ gradient strips.

\section{In-gel protein digestion and mass spectrometry}

The silver-stained protein spots were manually excised from the gels, and each was placed into a well of a 96-well microplate. The gel pieces were destained in a solution prepared from a $1: 1(\mathrm{v} / \mathrm{v})$ mixture of $30 \mathrm{mM}$ potassium ferricyanide and $100 \mathrm{mM}$ sodium thiosulfate at room temperature for $10 \mathrm{~min}$, vortexed until destained, washed three times with $300 \mu \mathrm{L}$ of Milli-Q water (each time for $5 \mathrm{~min}$ ) and dehydrated in $150 \mu \mathrm{L}$ of acetonitrile. Then the gel samples were swollen in $50 \mathrm{mM} \mathrm{NH} \mathrm{NHCO}_{3}$ containing $12.5 \mathrm{ng} / \mu \mathrm{L}$ trypsin (Sigma, Cat. No. $089 \mathrm{~K} 6048$ ) at $4^{\circ} \mathrm{C}$ for $30 \mathrm{~min}$, and at $37^{\circ} \mathrm{C}$ for longer than $12 \mathrm{~h}$. For each digest, the peptides were extracted from the gels twice with $5 \%$ trifluoroacetic/50\% acetonitrile at room temperature, resuspended in $0.7 \mu \mathrm{L}$ of $0.2 \mathrm{M} \alpha$-cyano-4-hydroxy-cinnamic acid (Sigma) in $0.1 \%$ trifluoroacetic/50\% acetonitrile, and allowed to dry under a stream of nitrogen. The extracted peptides were subjected to matrix-assisted laser desorption/ionization time-of-flight MS (4800 Proteomic Analyzer Applied Biosystems). Proteins were identified using the Peptide Mass Fingerprinting module of Mascot (Matrix Science) and the experimental masses of the peptides. We searched the Swissprot database in September 2010 (version 20100906, which included 519348 sequences and 183273162 residues) for proteins from Viridiplantae (green plants, 29439 sequences). One missed cleavage per peptide was allowed, and a mass tolerance of 50-150 ppm was used. Carbamidomethylation of cysteine was set as a fixed modification, and oxidation of methionine was allowed. Identified proteins with a peptide mass fingerprint were denoted as having an unambiguous identification by the following criteria:
(1) at least five different predicted peptide masses were needed to match the observed masses for an identification to be considered valid; and (2) protein scores needed to have $>57$ identity for Swissprot database $(\mathrm{p}<0.05)$.

\section{Gene ontology (GO) annotation and protein classification}

The UniProt database (http://www.uniprot.org) was searched to determine the functions of the identified proteins. Three independent ontological sets in the Viridiplantae taxonomic database were used to annotate and group the proteins according to biological processes, molecular function, and cellular compartmentalization.

\section{Protein-protein interactions (PPIs)}

PPIs were predicted by Cytoprophet, which is a plug-in of Cytoscape. We sent all the data for the identified proteins in I-1 and I-2 to the Cytoprophet server along with the set cover approach maximum specificity set cover (MSSC). The algorithm was used to predict the interaction network(s).

\section{Results and discussion}

\section{Proteome analysis and protein identification}

We investigated the differences between the I-1 and 1-2 protein profiles. More than 503 I-1 and 1127 I-2 protein spots were reproducibly detected (Figure 2). The pIs of the protein spots ranged from 3.5 to 9.3 , and the molecular masses ranged from 7.1 to $60.2 \mathrm{kDa}$.

For protein identification, the peptide mass fingerprinting data were used in conjunction with a search of the complete Swissprot Viridiplantae taxonomic database as only 1017 F. ananassa protein sequences were available therein. Respectively, 164 and 200 spots from the I- 1 and I-2 gels were selected for MS, and 38 and 52 proteins were identified, i.e., $\sim 25 \%$ of the total in each case (Tables 1 and 2). No unambiguous matches were made for the other 274 proteins, probably because the proteins were not included in the database or because a protein spot contained more than one protein. For the 90 identified proteins, 5 (6.5\%) were common to both proteomes, which indicated that the two internodes had some proteins (probably housekeeping proteins) in common. Certain proteins (35\% of the gene products) were specific to I- 1 , whereas $58.5 \%$ were specific to I-2 (Figure 3). More than $50 \%$ of the proteins could be correlated with annotated proteins from at least one dicotyledon species (Figure 4). Of the F. ananassa proteins identified in our study, 13 I-1 and 25 I-2 proteins were matched to Arabidopsis thaliana proteins, and others were matched to Oryza sativa proteins (two from I-1, six from I-2) and Zea mays proteins (three from I-1, two from I-2). Only five I-1 proteins and three I-2 proteins could be matched to those found in the F. ananassa database, possibly because the number of annotated proteins 


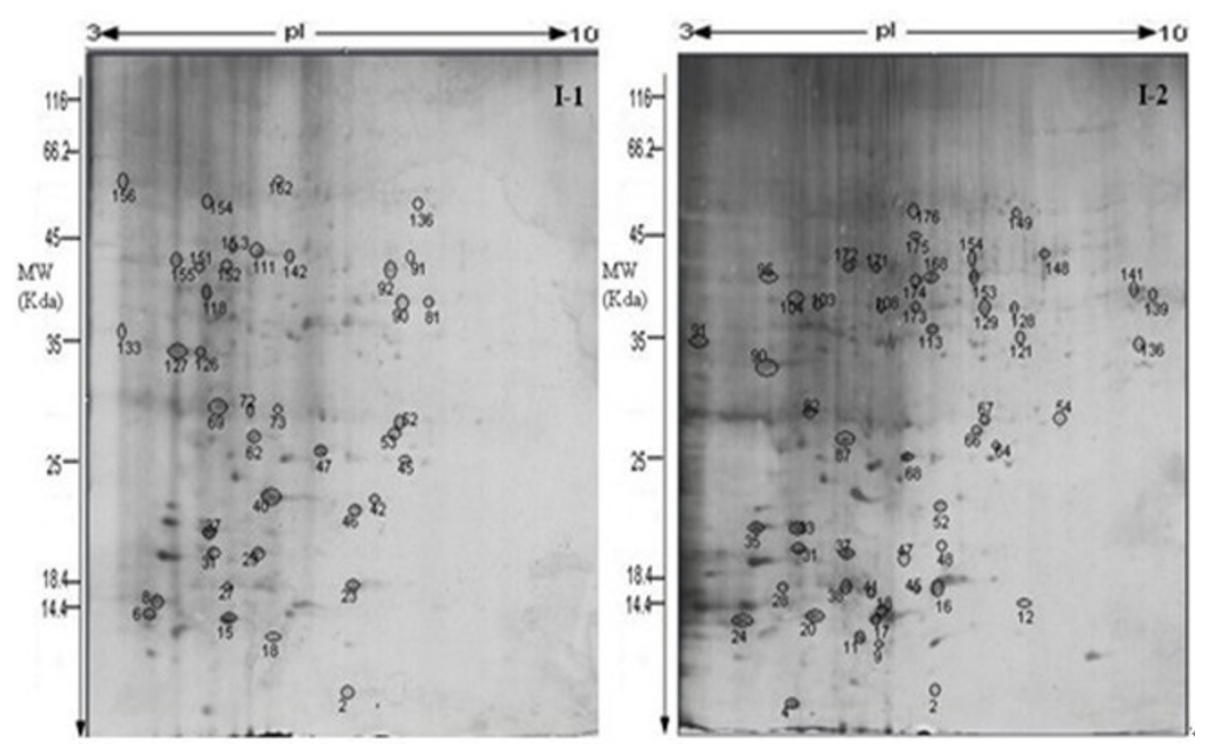

Figure 2 Two-dimensional SDS-PAGE gels of the I-1 and I-2 proteomes. Proteins $(300 \mu \mathrm{g})$ in $\mathrm{I}-1$ and $\mathrm{I}-2$ extracts were separated, in the first dimension by isoelectric focusing ( $\mathrm{pH}$ 3-10) and in the second dimension by SDS-PAGE through $12.5 \%$ acrylamide gels. Proteins were visualized by silver staining. Circled proteins were identified by matrix-assisted laser desorption/ionization time-of-flight MS and database searches.

contained in the database is relatively small compared with that for the A. thaliana database.

\section{Protein isoforms and subunits of protein complexes}

Isoforms for malate dehydrogenase (spots 15, 90, and 91), glucan endo-1,3- $\beta$-glucosidase 6 (spots 29 and 31), triosephosphate isomerase (spots 69 and 72), oxygenevolving enhancer protein 1 (spots 126 and 127), and a putative F-box/kelch-repeat protein (spots 62 and 151) were found in the I-1 proteome, and isoforms for malate dehydrogenase (spots 129 and 141), U-box domain-containing protein 34 (spots 153 and 175), and the probable protein ABIL5 (spots 12 and 48) were found for I-2 (Tables 1 and 2). Therefore, respectively, $\sim 29 \%$ and $\sim 12 \%$ of the identified I-1 and I- 2 proteins exist as isoforms. Previous studies reported that $\sim 70 \%$ of maize or Arabidopsis proteins exist as isoforms [12,13]. The experimental masses and/or pIs of certain proteins differed from their theoretical values, possibly owing to co-translational and/or post-translational modification (e.g., glycosylation, phosphorylation, and/or proteolysis), translation from alternatively spliced mRNAs [14-17], or post-translational modification by a nonprotein component(s) [18].

Of the 90 identified proteins, 16 (more than 17\%) form complexes [19]. For example, two I-1 spots corresponded to the $\alpha$ and $\beta$ subunits of chloroplastic ATP synthase. The $\beta$-subunit of the DNA-directed RNA polymerase subunit was detected in both the I-1 and I-2 proteomes. For some complexes, all component subunits were detected; for instance, both the small and large subunits of ribulose-bisphosphate carboxylase/oxygenase ( $\mathrm{RuBis} C \mathrm{C})$ were identified in the I-1 proteome. The fact that several complexes were identified will facilitate future studies of how complex formation is regulated. The components of a protein complex would be expected to be coordinately expressed and regulated to keep a system in functional balance. Thus, our 2-DE reference maps can be used to compare the levels of functionally related polypeptides (isoforms and subunits of complexes) and may provide insights into protein function and participation in molecular networks.

\section{Functional classification and subcellular localization of the identified proteins}

Identification of proteins that are differentially expressed in I-1 and I-2 is important for our understanding of internodal development and differentiation. The identified proteins were grouped according to their biological processes, i.e., photosynthesis, protein synthesis, protein folding, transcription, transport, stress, and development, and cellular locations using the GO annotation in the Viridiplantae taxonomic databases (Figures 5 and 6). Proteins involved in metabolism and photosynthesis accounted for $32 \%$ and $18 \%$, respectively, of the I-1 proteins. The numbers of I-1 proteins involved in transcription (13\%) and energy production (8\%) were also substantial. Interestingly, for I-2, although still the largest two groups, metabolic proteins accounted for only $15 \%$ and those involved in photosynthesis for $16 \%$. I-2 proteins involved in protein synthesis and DNA transcription each accounted for $12 \%$ of the total. The function 
Table 1 Identified proteins from the strawberry stolon I-1 internode

\begin{tabular}{|c|c|c|c|c|c|c|c|c|c|}
\hline $\begin{array}{l}\text { Spot } \\
\text { No. }^{a}\end{array}$ & Protein & $\begin{array}{l}\text { Accession } \\
\text { Number }^{b}\end{array}$ & $\begin{array}{l}\text { Molecular } \\
\text { Function }\end{array}$ & $\begin{array}{l}\text { Reference } \\
\text { Organism }\end{array}$ & $\begin{array}{l}\text { Theoretical } \\
\mathrm{kDa} / \mathrm{pl}^{d}\end{array}$ & $\begin{array}{l}\text { Experimental } \\
\mathrm{kDa} / \mathrm{pl}^{e}\end{array}$ & Score $^{f}$ & $\begin{array}{l}\mathrm{SC}^{g} \\
(\%)\end{array}$ & $\begin{array}{l}\text { Matched// } \\
\text { Unmatched } \\
\text { queries }^{h}\end{array}$ \\
\hline & Metabolism & & & & & & & & \\
\hline 15 & Malate dehydrogenase & P83373 & $\begin{array}{l}\text { L-malate } \\
\text { dehydrogenase } \\
\text { activity }\end{array}$ & $\begin{array}{l}\text { Fragaria } \\
\text { ananassa }\end{array}$ & $35.8 / 8.7$ & $13.5 / 5.3$ & 99 & 41 & $9 / 43$ \\
\hline 29 & $\begin{array}{l}\text { Glucan endo-1,3-beta- } \\
\text { glucosidase } 6\end{array}$ & Q93Z08 & $\begin{array}{l}\text { glucan endo-1,3- } \\
\text { beta-D-glucosidase } \\
\text { activity }\end{array}$ & $\begin{array}{l}\text { Arabidopsis } \\
\text { thaliana }\end{array}$ & $52.6 / 5.6$ & $20.3 / 5.8$ & 58 & 27 & $6 / 35$ \\
\hline 31 & $\begin{array}{l}\text { Glucan endo-1,3-beta- } \\
\text { glucosidase } 6\end{array}$ & Q93Z08 & $\begin{array}{l}\text { glucan endo-1,3- } \\
\text { beta-D-glucosidase } \\
\text { activity }\end{array}$ & $\begin{array}{l}\text { Arabidopsis } \\
\text { thaliana }\end{array}$ & $52.6 / 5.6$ & $20.4 / 5.0$ & 63 & 21 & $5 / 42$ \\
\hline 40 & Uricase & 004420 & $\begin{array}{l}\text { urate oxidase } \\
\text { activity }\end{array}$ & $\begin{array}{l}\text { Arabidopsis } \\
\text { thaliana }\end{array}$ & $35.0 / 8.6$ & $23.4 / 6.1$ & 58 & 38 & 10/107 \\
\hline 42 & $\begin{array}{l}\text { GDSL esterase/lipase } \\
\text { At } 4 \text { g } 16220\end{array}$ & 023469 & $\begin{array}{l}\text { hydrolase activity, } \\
\text { acting on ester } \\
\text { bonds }\end{array}$ & $\begin{array}{l}\text { Arabidopsis } \\
\text { thaliana }\end{array}$ & $26.7 / 8.9$ & $23.2 / 7.8$ & 57 & 37 & $6 / 36$ \\
\hline 90 & $\begin{array}{l}\text { Malate dehydrogenase, } \\
\text { mitochondrial }\end{array}$ & P83373 & $\begin{array}{l}\text { L-malate } \\
\text { dehydrogenase } \\
\text { activity }\end{array}$ & $\begin{array}{l}\text { Fragaria } \\
\text { ananassa }\end{array}$ & $35.8 / 8.7$ & $40.3 / 8.2$ & 122 & 51 & $10 / 50$ \\
\hline 91 & $\begin{array}{l}\text { Malate dehydrogenase, } \\
\text { mitochondrial }\end{array}$ & P83373 & $\begin{array}{l}\text { L-malate } \\
\text { dehydrogenase } \\
\text { activity }\end{array}$ & $\begin{array}{l}\text { Fragaria } \\
\text { ananassa }\end{array}$ & $35.8 / 8.7$ & $43.3 / 8.3$ & 100 & 50 & $9 / 45$ \\
\hline 111 & $\begin{array}{l}\text { S-adenosylmethionine } \\
\text { synthase }\end{array}$ & Q8W3Y4 & metal ion binding & $\begin{array}{l}\text { Phaseolus } \\
\text { lunatus }\end{array}$ & $43.5 / 5.6$ & $47.4 / 5.8$ & 74 & 24 & $7 / 9$ \\
\hline 118 & $\begin{array}{l}\text { 2,3-bisphosphoglycerate- } \\
\text { independent } \\
\text { phosphoglycerate mutase }\end{array}$ & P30792 & $\begin{array}{l}\text { manganese ion } \\
\text { binding }\end{array}$ & Zea mays & $60.7 / 5.2$ & $41.3 / 4.9$ & 59 & 24 & $8 / 27$ \\
\hline 133 & Fructokinase-1 & A2WXV8 & ATP binding & Oryza sativa & $34878 / 5.1$ & $36.1 / 3.8$ & 76 & 23 & $6 / 15$ \\
\hline 142 & $\begin{array}{l}\text { S-adenosylmethionine } \\
\text { synthase } 4\end{array}$ & A9PHC5 & metal ion binding & $\begin{array}{l}\text { Populus } \\
\text { trichocarpa }\end{array}$ & $42999 / 5.7$ & $46.5 / 6.3$ & 74 & 18 & $5 / 2$ \\
\hline \multirow[t]{2}{*}{162} & Phosphoglucomutase & P93804 & $\begin{array}{l}\text { magnesium ion } \\
\text { binding }\end{array}$ & Zea mays & $63286 / 5.4$ & $60.2 / 6.1$ & 63 & 17 & $9 / 30$ \\
\hline & Energy & & & & & & & & \\
\hline 152 & $\begin{array}{l}\text { ATP synthase subunit } \\
\text { beta, chloroplastic }\end{array}$ & Q9MRR9 & ATP binding & $\begin{array}{l}\text { Brasenia } \\
\text { schreberi }\end{array}$ & $53.8 / 5.2$ & $45.3 / 4.8$ & 76 & 27 & $8 / 19$ \\
\hline 153 & ATP synthase subunit beta & Q01859 & ATP binding & Oryza sativa & $59.0 / 5.9$ & $48.1 / 5.4$ & 134 & 44 & $19 / 45$ \\
\hline 155 & ATP synthase subunit beta & Q6QBP2 & ATP binding & Castanea sativa & $53.8 / 5.3$ & $45.9 / 4.4$ & 108 & 37 & $15 / 26$ \\
\hline \multirow[t]{2}{*}{156} & $\begin{array}{l}\text { ATP synthase subunit } \\
\text { alpha }\end{array}$ & A4QJA0 & ATP binding & $\begin{array}{l}\text { Aethionema } \\
\text { cordifolium }\end{array}$ & $55.3 / 5.2$ & $58.5 / 3.5$ & 114 & 22 & $10 / 13$ \\
\hline & Photosynthesis & & & & & & & & \\
\hline 2 & $\begin{array}{l}\text { Ribulose bisphosphate } \\
\text { carboxylase small chain } \\
1 \mathrm{~A}\end{array}$ & P10795 & $\begin{array}{l}\text { monooxygenase } \\
\text { activity }\end{array}$ & $\begin{array}{l}\text { Arabidopsis } \\
\text { thaliana }\end{array}$ & $20.5 / 7.6$ & $10.7 / 7.8$ & 62 & 43 & $7 / 101$ \\
\hline 37 & $\begin{array}{l}\text { Ribulose bisphosphate } \\
\text { carboxylase large chain } \\
\text { (Fragment) }\end{array}$ & O98681 & $\begin{array}{l}\text { ribulose- } \\
\text { bisphosphate } \\
\text { carboxylase activity }\end{array}$ & $\begin{array}{l}\text { Zamioculcas } \\
\text { zamiifolia }\end{array}$ & $49.9 / 6.3$ & $21.4 / 4.9$ & 79 & 25 & $10 / 78$ \\
\hline 46 & $\begin{array}{l}\text { Ribulose bisphosphate } \\
\text { carboxylase large chain }\end{array}$ & P28439 & $\begin{array}{l}\text { magnesium ion } \\
\text { binding }\end{array}$ & $\begin{array}{l}\text { Pelargonium } \\
\text { hortorum }\end{array}$ & $53.3 / 6.3$ & $23.7 / 7.5$ & 62 & 32 & $13 / 104$ \\
\hline 69 & $\begin{array}{l}\text { Triosephosphate } \\
\text { isomerase }\end{array}$ & Q9M4S8 & $\begin{array}{l}\text { triose-phosphate } \\
\text { isomerase activity }\end{array}$ & $\begin{array}{l}\text { Fragaria } \\
\text { ananassa }\end{array}$ & $33.7 / 7.6$ & $30.0 / 5.1$ & 152 & 55 & $19 / 112$ \\
\hline 72 & $\begin{array}{l}\text { Triosephosphate } \\
\text { isomerase }\end{array}$ & Q9M4S8 & $\begin{array}{l}\text { triose-phosphate } \\
\text { isomerase activity }\end{array}$ & $\begin{array}{l}\text { Fragaria } \\
\text { ananassa }\end{array}$ & $33.7 / 7.6$ & $31.3 / 5.6$ & 126 & 59 & $16 / 77$ \\
\hline 126 & $\begin{array}{l}\text { Oxygen-evolving } \\
\text { enhancer protein } 1\end{array}$ & P26320 & calcium ion binding & $\begin{array}{l}\text { Solanum } \\
\text { tuberosum }\end{array}$ & $35.6 / 5.8$ & $35.6 / 4.4$ & 111 & 33 & $8 / 8$ \\
\hline 127 & $\begin{array}{l}\text { Oxygen-evolving } \\
\text { enhancer protein } 1\end{array}$ & P26320 & calcium ion binding & $\begin{array}{l}\text { Solanum } \\
\text { tuberosum }\end{array}$ & $35.6 / 5.8$ & $34.9 / 4.8$ & 113 & 28 & $9 / 21$ \\
\hline
\end{tabular}


Table 1 Identified proteins from the strawberry stolon I-1 internode (Continued)

\begin{tabular}{|c|c|c|c|c|c|c|c|c|c|}
\hline & Transcription & & & & & & & & \\
\hline 6 & $\begin{array}{l}\text { Histone acetyltransferase } \\
\text { GCN5 }\end{array}$ & Q9AR19 & protein binding & $\begin{array}{l}\text { Arabidopsis } \\
\text { thaliana }\end{array}$ & $63.5 / 6.0$ & $14.2 / 4.1$ & 59 & 29 & $11 / 66$ \\
\hline 18 & $\begin{array}{l}\text { Pentatricopeptide repeat- } \\
\text { containing protein } \\
\text { At3g09650 }\end{array}$ & Q9SF38 & nucleotide binding & $\begin{array}{l}\text { Arabidopsis } \\
\text { thaliana }\end{array}$ & $84.4 / 6.5$ & $11.2 / 6.2$ & 80 & 23 & $14 / 49$ \\
\hline 27 & $\begin{array}{l}\text { Transcription factor } \\
\text { bHLH145 }\end{array}$ & Q9FGB0 & DNA binding & $\begin{array}{l}\text { Arabidopsis } \\
\text { thaliana }\end{array}$ & $35.2 / 5.1$ & $18.3 / 5.1$ & 62 & 28 & $10 / 63$ \\
\hline 92 & $\begin{array}{l}\text { DNA-directed RNA } \\
\text { polymerase subunit beta }\end{array}$ & B1VKH5 & $\begin{array}{l}\text { DNA-directed RNA } \\
\text { polymerase activity }\end{array}$ & $\begin{array}{l}\text { Cryptomeria } \\
\text { japonica }\end{array}$ & 139.6/9.4 & $44.6 / 8.1$ & 59 & 12 & $11 / 65$ \\
\hline \multirow[t]{2}{*}{136} & DNA polymerase & P10582 & $\begin{array}{l}3^{\prime}-5^{\prime} \text { exonuclease } \\
\text { activity }\end{array}$ & Zea mays & $108.2 / 8.6$ & $55.3 / 8.5$ & 58 & 15 & $8 / 23$ \\
\hline & Protein synthesis & & & & & & & & \\
\hline \multirow[t]{2}{*}{154} & $50 S$ ribosomal protein L33 & B2LML4 & $\begin{array}{l}\text { structural } \\
\text { constituent of } \\
\text { ribosome }\end{array}$ & $\begin{array}{l}\text { Guizotia } \\
\text { abyssinica }\end{array}$ & $7.8 / 9.7$ & $56.4 / 5.1$ & 62 & 42 & $5 / 11$ \\
\hline & $\begin{array}{l}\text { Protein folding, } \\
\text { degradation and } \\
\text { assembly }\end{array}$ & & & & & & & & \\
\hline 45 & Heat shock protein 81-3 & P51818 & ATP binding & $\begin{array}{l}\text { Arabidopsis } \\
\text { thaliana }\end{array}$ & $80.2 / 5.0$ & $26.7 / 8.2$ & 59 & 19 & $9 / 85$ \\
\hline \multirow[t]{2}{*}{73} & $\begin{array}{l}\text { Proteasome subunit alpha } \\
\text { type-6 }\end{array}$ & O48551 & $\begin{array}{l}\text { threonine-type } \\
\text { endopeptidase } \\
\text { activity }\end{array}$ & Glycine max & $27.5 / 5.8$ & $28.3 / 6.1$ & 58 & 31 & $6 / 62$ \\
\hline & Transport & & & & & & & & \\
\hline 23 & $\begin{array}{l}\mathrm{NAD}(\mathrm{P}) \mathrm{H} \text {-quinone } \\
\text { oxidoreductase subunit } \mathrm{H}, \\
\text { chloroplastic OS }\end{array}$ & $\mathrm{A} 6 \mathrm{MMH} 1$ & $\begin{array}{l}\text { oxidoreductase } \\
\text { activity, acting on } \\
\text { NADH or NADPH }\end{array}$ & $\begin{array}{l}\text { Chloranthus } \\
\text { spicatus }\end{array}$ & $45.8 / 5.4$ & $18.5 / 7.3$ & 75 & 26 & $12 / 66$ \\
\hline \multirow[t]{2}{*}{52} & Ras-related protein ARA-4 & P28187 & GTP binding & $\begin{array}{l}\text { Arabidopsis } \\
\text { thaliana }\end{array}$ & $24.1 / 5.0$ & $28.6 / 8.4$ & 61 & 28 & $10 / 101$ \\
\hline & Stress Related & & & & & & & & \\
\hline 62 & $\begin{array}{l}\text { Putative F-box/kelch- } \\
\text { repeat protein At4g19330 }\end{array}$ & O65704 & N/A & $\begin{array}{l}\text { Arabidopsis } \\
\text { thaliana }\end{array}$ & $62.9 / 7.1$ & $27.3 / 5.7$ & 59 & 25 & $10 / 82$ \\
\hline \multirow[t]{2}{*}{151} & $\begin{array}{l}\text { Putative F-box/kelch- } \\
\text { repeat protein At4g19330 }\end{array}$ & O65704 & N/A & $\begin{array}{l}\text { Arabidopsis } \\
\text { thaliana }\end{array}$ & $62.8 / 7.1$ & $44.3 / 4.8$ & 65 & 21 & $8 / 75$ \\
\hline & Development & & & & & & & & \\
\hline 53 & 3-ketoacyl-CoA synthase 5 & Q9C6L5 & $\begin{array}{l}\text { fatty acid elongase } \\
\text { activity }\end{array}$ & $\begin{array}{l}\text { Arabidopsis } \\
\text { thaliana }\end{array}$ & $56.3 / 9.0$ & $27.7 / 8.1$ & 61 & 40 & $12 / 19$ \\
\hline \multirow[t]{2}{*}{81} & $\begin{array}{l}\text { Cytoplasmic dynein } 2 \\
\text { heavy chain } 1\end{array}$ & Q9SMH5 & ATP binding & $\begin{array}{l}\text { Chlamydomonas } \\
\text { reinhardtii }\end{array}$ & $483.5 / 6.1$ & $40.0 / 8.6$ & 58 & 7 & $22 / 48$ \\
\hline & Unknown & & & & & & & & \\
\hline 8 & $\begin{array}{l}\text { Embryonic abundant } \\
\text { protein VF30.1 OS = Vicia } \\
\text { faba } \mathrm{PE}=2 \mathrm{SV}=1\end{array}$ & P21745 & N/A & Vicia faba & $30.1 / 6.4$ & $18.1 / 4.2$ & 67 & 33 & $7 / 67$ \\
\hline
\end{tabular}

${ }^{a}$ As indicated in Figure $2 .{ }^{b}$ Swissprot database accession number. ${ }^{c}$ Molecular functions were inferred from those reported in the UniProt database. ${ }^{d}$ Theoretical isoelectric point and molecular mass. ${ }^{e}$ Experimental isoelectric point and molecular mass. ${ }^{f}$ Mascot score. ${ }^{g}$ Sequence coverage. ${ }^{h}$ Number of matched and unmatched peptides.

could not be determined for $3 \%$ of the identified I-1 proteins and $\sim 13 \%$ of the I- 2 proteins. The percentage of unidentified I-2 proteins is similar to those found for maize [20], rice [21] or oilseed rape [22]. The substantial differences in the numbers of I- 1 and I-2 proteins involved in metabolism, energy production, and protein synthesis suggest that the functions of these proteins during development deserve further attention.

Subcellular localization provides important information about a protein's physiological function [23,24]. Recently,
GO annotation has been widely used to predict the locations of proteins [25-29], because the two are strongly correlated. We found most of the identified proteins to be located in chloroplasts and mitochondria, which is congruent with total genomic data available for plants [30]. Interestingly, most of these proteins are involved in metabolism or energy production, which is consistent with the large number of proteins that we classified as metabolic or photosynthetic. We could not identify the cellular location of $\sim 11 \%$ and $\sim 25 \%$ I- 1 and I-2 proteins, respectively. 
Table 2 Identified proteins from the strawberry stolon I-2 internode

\begin{tabular}{|c|c|c|c|c|c|c|c|c|c|}
\hline $\begin{array}{l}\text { Spot } \\
\text { No. }^{a}\end{array}$ & Protein & $\begin{array}{l}\text { Accession } \\
\text { Number }^{b}\end{array}$ & Molecular Function $^{c}$ & $\begin{array}{l}\text { Reference } \\
\text { Organism }\end{array}$ & $\begin{array}{l}\text { Theoretical } \\
\mathrm{kDa} / \mathrm{pl}^{d}\end{array}$ & $\begin{array}{l}\text { Experimental } \\
\mathrm{kDa} / \mathrm{pl}^{e}\end{array}$ & Score $^{f}$ & $\begin{array}{l}\mathrm{SC}^{g} \\
(\%)\end{array}$ & $\begin{array}{l}\text { Matched// } \\
\text { Unmatched } \\
\text { queries }^{h}\end{array}$ \\
\hline & Metabolism & & & & & & & & \\
\hline 91 & Fructokinase-1 & $\mathrm{A} 2 \mathrm{WXV} 8$ & ATP binding & Oryza sativa & $34.9 / 5.1$ & $35.8 / 3.4$ & 76 & 20 & $6 / 59$ \\
\hline 95 & $\begin{array}{l}\text { Caffeic acid 3-O- } \\
\text { methyltransferase }\end{array}$ & Q8GU25 & $\begin{array}{l}\text { caffeate } \mathrm{O}- \\
\text { methyltransferase activity }\end{array}$ & Rosa chinensis & $40.1 / 5.6$ & $43.7 / 4.4$ & 110 & 35 & $12 / 30$ \\
\hline 129 & $\begin{array}{l}\text { Malate dehydrogenase, } \\
\text { mitochondrial }\end{array}$ & P83373 & Oxidoreductase & $\begin{array}{l}\text { Fragaria } \\
\text { ananassa }\end{array}$ & $35.8 / 8.7$ & $39.1 / 7.8$ & 74 & 31 & $8 / 28$ \\
\hline 139 & $\begin{array}{l}\text { Glyceraldehyde-3-phosphate } \\
\text { dehydrogenase, cytosolic }\end{array}$ & P25858 & Oxidoreductase & $\begin{array}{l}\text { Arabidopsis } \\
\text { thaliana }\end{array}$ & $37.0 / 6.6$ & $40.1 / 9.3$ & 74 & 29 & $9 / 27$ \\
\hline 141 & $\begin{array}{l}\text { Malate dehydrogenase, } \\
\text { mitochondrial }\end{array}$ & P83373 & Oxidoreductase & $\begin{array}{l}\text { Fragaria } \\
\text { ananassa }\end{array}$ & $35.8 / 8.7$ & $41.0 / 9.1$ & 65 & 27 & $6 / 23$ \\
\hline 172 & $\begin{array}{l}\text { S-adenosylmethionine } \\
\text { synthase } 2\end{array}$ & Q9FUZ1 & ATP binding & Brassica juncea & $43.3 / 5.3$ & 43.9/5.9 & 138 & 44 & $15 / 36$ \\
\hline 173 & $\begin{array}{l}\text { S-adenosylmethionine } \\
\text { synthase }\end{array}$ & A4PU48 & ATP binding & $\begin{array}{l}\text { Medicago } \\
\text { truncatula }\end{array}$ & $43.7 / 5.6$ & $38.5 / 6.8$ & 178 & 52 & $15 / 17$ \\
\hline \multirow[t]{2}{*}{174} & $\begin{array}{l}\text { S-adenosylmethionine } \\
\text { synthase }\end{array}$ & Q8W3Y4 & ATP binding & $\begin{array}{l}\text { Phaseolus } \\
\text { lunatus }\end{array}$ & $43.5 / 5.6$ & $41.2 / 6.7$ & 132 & 48 & $15 / 40$ \\
\hline & Energy & & & & & & & & \\
\hline \multirow[t]{2}{*}{176} & $\begin{array}{l}\text { ATP synthase subunit beta, } \\
\text { plastid }\end{array}$ & Q8MBG5 & ATP binding & $\begin{array}{l}\text { Cuscuta } \\
\text { pentagona }\end{array}$ & $53.2 / 5.5$ & $53.4 / 6.7$ & 61 & 32 & $10 / 53$ \\
\hline & Photosynthesis & & & & & & & & \\
\hline 17 & $\begin{array}{l}\text { Probable alpha,alpha- } \\
\text { trehalose-phosphate } \\
\text { synthase [UDP-forming] } 40 S\end{array}$ & Q9T079 & $\begin{array}{l}\text { alpha,alpha-trehalose- } \\
\text { phosphate synthase } \\
\text { (UDP-forming) activity }\end{array}$ & $\begin{array}{l}\text { Arabidopsis } \\
\text { thaliana }\end{array}$ & $90.3 / 6.1$ & $14.2 / 6.3$ & 58 & 25 & $12 / 66$ \\
\hline 33 & $\begin{array}{l}\text { Ribulose bisphosphate } \\
\text { carboxylase large chain } \\
\text { (Fragment) OS }\end{array}$ & P28261 & magnesium ion binding & Nypa fruticans & $51.5 / 6.2$ & $22.3 / 5.1$ & 123 & 23 & $13 / 61$ \\
\hline 35 & $\begin{array}{l}\text { Probable granule-bound } \\
\text { starch synthase 1, } \\
\text { chloroplastic/amyloplastic }\end{array}$ & Q9MAQ0 & starch synthase activity & $\begin{array}{l}\text { Arabidopsis } \\
\text { thaliana }\end{array}$ & $67.5 / 8.7$ & 23.0/4.5 & 60 & 24 & $9 / 37$ \\
\hline 52 & $\begin{array}{l}\text { Ribulose bisphosphate } \\
\text { carboxylase large chain } \\
\text { (Fragment) }\end{array}$ & P28391 & magnesium ion binding & $\begin{array}{l}\text { Ceratopetalum } \\
\text { gummiferum }\end{array}$ & $51.3 / 6.2$ & $24.0 / 6.9$ & 104 & 22 & $11 / 63$ \\
\hline 64 & $\begin{array}{l}\text { Ribulose-phosphate 3- } \\
\text { epimerase, chloroplastic }\end{array}$ & Q43157 & $\begin{array}{l}\text { ribulose-phosphate 3- } \\
\text { epimerase activity }\end{array}$ & $\begin{array}{l}\text { Spinacia } \\
\text { oleracea }\end{array}$ & $30.6 / 8.2$ & $27.2 / 7.9$ & 58 & 31 & $6 / 51$ \\
\hline 82 & $\begin{array}{l}\text { Triosephosphate isomerase, } \\
\text { chloroplastic }\end{array}$ & Q9M4S8 & $\begin{array}{l}\text { triose-phosphate } \\
\text { isomerase activity }\end{array}$ & $\begin{array}{l}\text { Fragaria } \\
\text { ananassa }\end{array}$ & $33.7 / 7.6$ & $31.5 / 5.2$ & 154 & 51 & $16 / 71$ \\
\hline 90 & $\begin{array}{l}\text { Oxygen-evolving enhancer } \\
\text { protein } 1 \text {, chloroplastic }\end{array}$ & P26320 & calcium ion binding & $\begin{array}{l}\text { Solanum } \\
\text { tuberosum }\end{array}$ & $35.6 / 5.8$ & $34.5 / 4.7$ & 98 & 31 & $10 / 48$ \\
\hline 103 & $\begin{array}{l}\text { Coproporphyrinogen-III } \\
\text { oxidase, chloroplastic }\end{array}$ & P35055 & $\begin{array}{l}\text { coproporphyrinogen } \\
\text { oxidase activity }\end{array}$ & Glycine max & $43.6 / 6.7$ & $42.2 / 5.2$ & 84 & 31 & $10 / 32$ \\
\hline \multirow[t]{2}{*}{104} & $\begin{array}{l}\text { Glutamyl-tRNA reductase 1, } \\
\text { chloroplastic }\end{array}$ & Q42843 & NADP or NADPH binding & $\begin{array}{l}\text { Hordeum } \\
\text { vulgare }\end{array}$ & $58.1 / 8.7$ & $42.1 / 4.9$ & 70 & 24 & $11 / 48$ \\
\hline & Transcription & & & & & & & & \\
\hline 18 & $\begin{array}{l}\text { Homeobox-leucine zipper } \\
\text { protein GLABRA } 2 \text { OS }\end{array}$ & P46607 & $\begin{array}{l}\text { sequence-specific DNA } \\
\text { binding }\end{array}$ & $\begin{array}{l}\text { Arabidopsis } \\
\text { thaliana }\end{array}$ & $83.7 / 6.1$ & $15.0 / 6.4$ & 63 & 31 & $20 / 90$ \\
\hline 47 & Protein HIRA & Q32SG6 & $\begin{array}{l}\text { transcription regulator } \\
\text { activity }\end{array}$ & Zea mays & $106.55 / 7.8$ & 19.7/7.1 & 60 & 22 & $16 / 90$ \\
\hline 121 & $\begin{array}{l}\text { Two-component response } \\
\text { regulator ARR9 }\end{array}$ & O80366 & $\begin{array}{l}\text { two-component } \\
\text { response regulator } \\
\text { activity }\end{array}$ & $\begin{array}{l}\text { Arabidopsis } \\
\text { thaliana }\end{array}$ & $26.2 / 5.2$ & $34.6 / 8.1$ & 58 & 35 & $5 / 43$ \\
\hline 128 & $\begin{array}{l}\text { DNA-directed RNA } \\
\text { polymerase subunit beta }\end{array}$ & P12465 & DNA binding & $\begin{array}{l}\text { Chlorella } \\
\text { vulgaris }\end{array}$ & $179.4 / 9.9$ & $36.9 / 8.0$ & 60 & 9 & $11 / 34$ \\
\hline 149 & $\begin{array}{l}\text { B3 domain-containing } \\
\text { protein Os07g0679700 }\end{array}$ & Q6Z3U3 & DNA binding & Oryza sativa & $105.4 / 6.5$ & $53.5 / 7.9$ & 63 & 11 & $9 / 27$ \\
\hline 168 & Protein HIRA & Q32SG6 & $\begin{array}{l}\text { transcription regulator } \\
\text { activity }\end{array}$ & Zea mays & $106.5 / 7.8$ & $41.1 / 6.8$ & 60 & 22 & $16 / 90$ \\
\hline
\end{tabular}


Table 2 Identified proteins from the strawberry stolon I-2 internode (Continued)

\begin{tabular}{|c|c|c|c|c|c|c|c|c|c|}
\hline & Protein synthesis & & & & & & & & \\
\hline 28 & $\begin{array}{l}\text { Eukaryotic translation } \\
\text { initiation factor } 5 \mathrm{~A}-2 \text { OS }\end{array}$ & Q945F4 & $\begin{array}{l}\text { translation initiation } \\
\text { factor activity }\end{array}$ & $\begin{array}{l}\text { Medicago } \\
\text { sativa }\end{array}$ & $17.5 / 5.4$ & $17.3 / 4.7$ & 74 & 26 & $5 / 39$ \\
\hline 37 & $\begin{array}{l}\text { Eukaryotic translation } \\
\text { initiation factor } 5 \mathrm{~A}\end{array}$ & Q9AXQ7 & $\begin{array}{l}\text { translation initiation } \\
\text { factor activity }\end{array}$ & $\begin{array}{l}\text { Dianthus } \\
\text { caryophyllus }\end{array}$ & $17.6 / 5.6$ & $20.3 / 5.9$ & 88 & 45 & $7 / 28$ \\
\hline 45 & $\begin{array}{l}\text { Glutathione gamma- } \\
\text { glutamylcysteinyltransferase } \\
2\end{array}$ & Q9ZWB7 & acyltransferase activity & $\begin{array}{l}\text { Arabidopsis } \\
\text { thaliana }\end{array}$ & $52.3 / 6.6$ & $16.4 / 6.6$ & 57 & 15 & $8 / 32$ \\
\hline 66 & $\begin{array}{l}\text { Phospho-2-dehydro-3- } \\
\text { deoxyheptonate aldolase 1, } \\
\text { chloroplastic }\end{array}$ & P21357 & $\begin{array}{l}\text { 3-deoxy-7- } \\
\text { phosphoheptulonate } \\
\text { synthase activity }\end{array}$ & $\begin{array}{l}\text { Solanum } \\
\text { tuberosum }\end{array}$ & $60.0 / 8.9$ & 27.9/7.3 & 62 & 31 & $11 / 71$ \\
\hline 87 & $\begin{array}{l}\text { Molybdenum cofactor } \\
\text { sulfurase }\end{array}$ & Q655R6 & lyase activity & Oryza sativa & $92.9 / 7.1$ & $27.2 / 5.2$ & 60 & 12 & $6 / 22$ \\
\hline \multirow[t]{2}{*}{136} & $\begin{array}{l}\text { Probable beta-1,3- } \\
\text { galactosyltransferase } 18\end{array}$ & Q8RX55 & $\begin{array}{l}\text { galactosyltransferase } \\
\text { activity }\end{array}$ & $\begin{array}{l}\text { Arabidopsis } \\
\text { thaliana }\end{array}$ & $77.9 / 8.7$ & $35.1 / 9.1$ & 66 & 17 & $7 / 27$ \\
\hline & $\begin{array}{l}\text { Protein folding, } \\
\text { degradation and assembly }\end{array}$ & & & & & & & & \\
\hline 148 & $\begin{array}{l}\text { Anaphase-promoting } \\
\text { complex subunit } 2\end{array}$ & Q8H1U5 & $\begin{array}{l}\text { ubiquitin protein ligase } \\
\text { binding }\end{array}$ & $\begin{array}{l}\text { Arabidopsis } \\
\text { thaliana }\end{array}$ & $98.4 / 4.8$ & $43.5 / 7.9$ & 64 & 12 & $7 / 20$ \\
\hline 153 & $\begin{array}{l}\text { U-box domain-containing } \\
\text { protein } 34\end{array}$ & Q8S8S7 & $\begin{array}{l}\text { ubiquitin-protein ligase } \\
\text { activity }\end{array}$ & $\begin{array}{l}\text { Arabidopsis } \\
\text { thaliana }\end{array}$ & $91.7 / 9.1$ & $39.6 / 6.9$ & 63 & 18 & $12 / 51$ \\
\hline 171 & $\begin{array}{l}\text { Ubiquitin carboxyl-terminal } \\
\text { hydrolase } 6\end{array}$ & Q949Y0 & $\begin{array}{l}\text { ubiquitin-specific } \\
\text { protease activity }\end{array}$ & $\begin{array}{l}\text { Arabidopsis } \\
\text { thaliana }\end{array}$ & $54.0 / 5.8$ & $41.6 / 5.8$ & 58 & 19 & $8 / 35$ \\
\hline \multirow[t]{2}{*}{175} & $\begin{array}{l}\text { U-box domain-containing } \\
\text { protein } 34\end{array}$ & Q8S8S7 & $\begin{array}{l}\text { ubiquitin-protein ligase } \\
\text { activity }\end{array}$ & $\begin{array}{l}\text { Arabidopsis } \\
\text { thaliana }\end{array}$ & $91.7 / 9.1$ & $44.7 / 6.2$ & 58 & 19 & $12 / 67$ \\
\hline & Transport & & & & & & & & \\
\hline 24 & $\begin{array}{l}\text { Magnesium transporter } \\
\text { MRS2-8 OS }\end{array}$ & Q8H1G7 & $\begin{array}{l}\text { metal ion } \\
\text { transmembrane } \\
\text { transporter activity }\end{array}$ & $\begin{array}{l}\text { Arabidopsis } \\
\text { thaliana }\end{array}$ & $43.1 / 5.3$ & $13.6 / 4.4$ & 58 & 22 & $6 / 34$ \\
\hline \multirow[t]{2}{*}{54} & $\begin{array}{l}\text { Putative copper-transporting } \\
\text { ATPase } 3\end{array}$ & Q9SH30 & ATP binding & $\begin{array}{l}\text { Arabidopsis } \\
\text { thaliana }\end{array}$ & 109.0/6.0 & 29.0/8.0 & 65 & 18 & $14 / 48$ \\
\hline & Stress Related & & & & & & & & \\
\hline 4 & $\begin{array}{l}\text { Ninja-family protein AFP4 } \\
\text { OS }\end{array}$ & Q9S7Z2 & protein binding & $\begin{array}{l}\text { Arabidopsis } \\
\text { thaliana }\end{array}$ & $35.6 / 8.5$ & $7.1 / 5.0$ & 57 & 40 & $9 / 70$ \\
\hline 9 & Glutathione S-transferase 6 & Q96266 & glutathione binding & $\begin{array}{l}\text { Arabidopsis } \\
\text { thaliana }\end{array}$ & $29.2 / 8.5$ & $11.9 / 6.2$ & 58 & 25 & $5 / 46$ \\
\hline 20 & Annexin D6 OS & Q9LX08 & calcium ion binding & $\begin{array}{l}\text { Arabidopsis } \\
\text { thaliana }\end{array}$ & $36.6 / 7.7$ & $14.0 / 5.1$ & 62 & 20 & $7 / 39$ \\
\hline 41 & $\begin{array}{l}\text { Monodehydroascorbate } \\
\text { reductase, chloroplastic }\end{array}$ & P92947 & $\begin{array}{l}\text { monodehydroascorbate } \\
\text { reductase (NADH) activity }\end{array}$ & $\begin{array}{l}\text { Arabidopsis } \\
\text { thaliana }\end{array}$ & $53.5 / 8.1$ & $16.2 / 5.7$ & 63 & 26 & $8 / 76$ \\
\hline \multirow[t]{2}{*}{154} & $\begin{array}{l}\text { Monodehydroascorbate } \\
\text { reductase }\end{array}$ & Q40977 & $\begin{array}{l}\text { monodehydroascorbate } \\
\text { reductase (NADH) activity }\end{array}$ & Pisum sativum & $47.3 / 5.8$ & $43.5 / 6.8$ & 58 & 22 & $7 / 31$ \\
\hline & Development & & & & & & & & \\
\hline 2 & $\begin{array}{l}\text { Pentatricopeptide repeat- } \\
\text { containing protein } \\
\text { At3g06430, chloroplastic OS }\end{array}$ & Q9SQU6 & N/A & $\begin{array}{l}\text { Arabidopsis } \\
\text { thaliana }\end{array}$ & $56.2 / 7.8$ & $9.5 / 6.7$ & 58 & 25 & $11 / 59$ \\
\hline 11 & Protein BRUSHY 1 & Q6Q4D0 & protein binding & $\begin{array}{l}\text { Arabidopsis } \\
\text { thaliana }\end{array}$ & $148.8 / 5.5$ & $12.0 / 5.9$ & 63 & 24 & $21 / 71$ \\
\hline 38 & Protein PAIR1 & Q75RY2 & & Oryza sativa & $53.8 / 9.8$ & $17.2 / 5.5$ & 66 & 19 & $10 / 34$ \\
\hline \multirow[t]{2}{*}{68} & $\begin{array}{l}\text { 1-aminocyclopropane-1- } \\
\text { carboxylate synthase } 7\end{array}$ & Q9STR4 & $\begin{array}{l}\text { 1-aminocyclopropane-1- } \\
\text { carboxylate synthase } \\
\text { activity }\end{array}$ & $\begin{array}{l}\text { Arabidopsis } \\
\text { thaliana }\end{array}$ & $51.0 / 5.9$ & $26.2 / 6.3$ & 57 & 19 & $10 / 72$ \\
\hline & Unknown & & & & & & & & \\
\hline 12 & Probable protein ABIL5 OS & Q5JMF2 & N/A & Oryza sativa & $28.3 / 8.3$ & $15.2 / 7.6$ & 59 & 40 & $7 / 42$ \\
\hline 16 & $\begin{array}{l}\text { Pentatricopeptide repeat- } \\
\text { containing protein } \\
\text { At4g26800 OS }\end{array}$ & Q9SZ20 & $\mathrm{N} / \mathrm{A}$ & $\begin{array}{l}\text { Arabidopsis } \\
\text { thaliana }\end{array}$ & $58.4 / 9.1$ & 16.1/6.8 & 64 & 32 & $12 / 49$ \\
\hline 31 & $\begin{array}{l}\text { Putative F-box protein } \\
\text { At1g20795 OS }\end{array}$ & Q9LM74 & N/A & $\begin{array}{l}\text { Arabidopsis } \\
\text { thaliana }\end{array}$ & $48.5 / 8.6$ & 20.3/5.1 & 60 & 21 & $8 / 55$ \\
\hline
\end{tabular}


Table 2 Identified proteins from the strawberry stolon I-2 internode (Continued)

\begin{tabular}{|c|c|c|c|c|c|c|c|c|c|}
\hline 48 & Probable protein ABIL5 OS & Q5JMF2 & $\mathrm{N} / \mathrm{A}$ & Oryza sativa & $28.2 / 8.2$ & $21.5 / 6.9$ & 59 & 40 & $7 / 42$ \\
\hline 67 & $\begin{array}{l}\text { BRCT domain-containing } \\
\text { protein At4g02110 }\end{array}$ & 004251 & $\mathrm{~N} / \mathrm{A}$ & $\begin{array}{l}\text { Arabidopsis } \\
\text { thaliana }\end{array}$ & $142.5 / 8.4$ & $28.4 / 7.5$ & 59 & 19 & $18 / 80$ \\
\hline 108 & $\begin{array}{l}\text { Thylakoid lumenal } 15.0 \mathrm{kDa} \\
\text { protein 2, chloroplastic }\end{array}$ & Q9LW5 & N/A & $\begin{array}{l}\text { Arabidopsis } \\
\text { thaliana }\end{array}$ & $24.7 / 5.7$ & $37.8 / 5.8$ & 68 & 26 & $7 / 37$ \\
\hline 113 & $\begin{array}{l}\text { Pentatricopeptide repeat- } \\
\text { containing protein } \\
\text { At2g01860 }\end{array}$ & Q5XET4 & $\mathrm{N} / \mathrm{A}$ & $\begin{array}{l}\text { Arabidopsis } \\
\text { thaliana }\end{array}$ & $56.0 / 9.2$ & $36.1 / 6.8$ & 59 & 39 & $15 / 95$ \\
\hline
\end{tabular}

${ }^{a}$ Spot number as in Figure $2 .{ }^{b}$ Swissprot database accession number. ${ }^{c}$ Molecular functions were inferred from those reported in the UniProt database. ${ }^{d}$ Theoretical molecular mass and isoelectric point. ${ }^{e}$ Experimental molecular mass and isoelectric point. ${ }^{f}$ Mascot score. ${ }^{g}$ Sequence coverage. ${ }^{h}$ Number of matched and unmatched peptides.

\section{Proteins involved in metabolism}

For I-1, identified proteins were found for lipid metabolism (spot 42), purine metabolism (spot 40), the citric acid cycle (spots 15, 90, and 91), starch and sucrose metabolism (spots 29, 31, 118, 133, and 162), and onecarbon metabolism (spots 111 and 142). For I-2, we found additional proteins involved in one-carbon metabolism (spots 172, 173, and 174) but fewer and different proteins involved in starch and sucrose metabolism (spots 91 and 139). Many more proteins involved in metabolism were found for I- 1 than for I-2 (Tables 1 and 2, Figure 5). The activities of extracellular lipase (spot 42) and $\beta-1,3$-glucanase (spots 29 and 31) have been implicated in pollen germination, fertilization, response to wounding, and cell division [31,32], all or any of which may be related to I-1 elongation via cell division. Sugars are involved in energy metabolism and act as signaling molecules. For I-1, we identified 2,3bisphosphoglycerate-independent phosphoglycerate mutase (spot 118) and phosphoglucomutase (spot 162), and for I-2, glyceraldehyde-3-phosphate dehydrogenase (spot 159), all of which are glycolytic enzymes. Interestingly, malate dehydrogenase (spots 90 and 129), fructokinase-1 (spots 155 and 91), and S-adenosyl-1-methionine

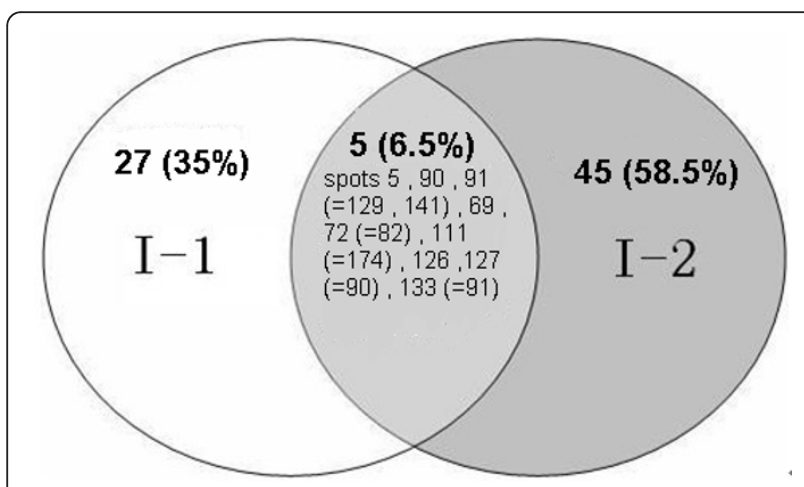

Figure 3 Venn diagram for the identified I-1 and I-2 proteins. The numbers and percentages of unique proteins (excluding isoforms) found for either or both internodes are given. Spot numbers for $1-1$ proteins are given first followed by spot numbers for the corresponding $1-2$ proteins in parentheses.
(AdoMet) synthase (spots 111 and 175) were identified in both I-1 and I- 2 proteomes. Malate dehydrogenase is a citric-acid-cycle enzyme that converts malate into oxaloacetate (using NAD). Fructokinase is involved in sucrose and fructose metabolism and may regulate starch synthesis in conjunction with sucrose synthase, which first metabolizes plant sink tissue in, for example, potatoes [33]. AdoMet synthase catalyzes the formation of AdoMet from methionine and ATP [34], which is the main methyl group donor and is involved in transmethylations and the trans-sulfuration pathway [35]. AdoMet is also involved in the biosynthesis of many secondary metabolites [36,37] and can be decarboxylated to generate a propylamine donor for polyamine biosynthesis [38]. Polyamines are required for cell proliferation and may play a role in the rapid growth of bloom-forming dinoflagellates [39]. In plants, AdoMet participates in ethylene biosynthesis [40] and is the methyl group donor in transmethylation of alkaloids [41]. Cell and life cycle variation in AdoMet synthase expression has been observed in yeast and apicomplexa $[42,43]$.

\section{Proteins involved in energy production}

More identified I-1 proteins (11\%) were found to be involved in energy production than were I-2 proteins (2\%, Figure 5). Both the $\alpha$ and $\beta$ subunits of chloroplastic

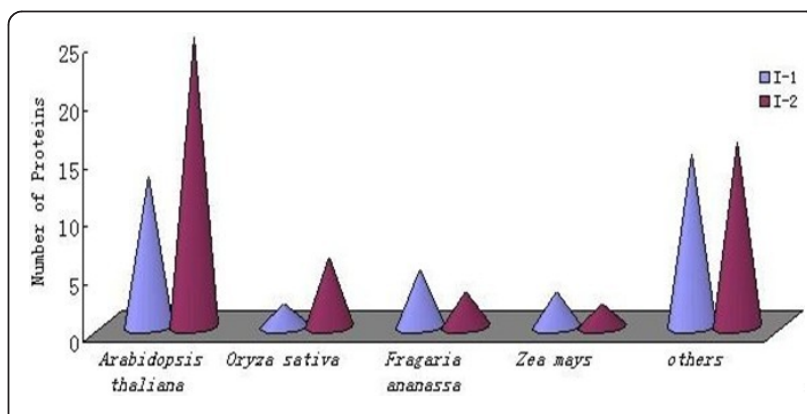

Figure 4 Number of proteins with sequences that matched those of organisms listed in the Swissprot Viridiplantae database. Over $50 \%$ of the proteins identified had sequences similar to annotated proteins from dicot species in the Viridiplantae database. 

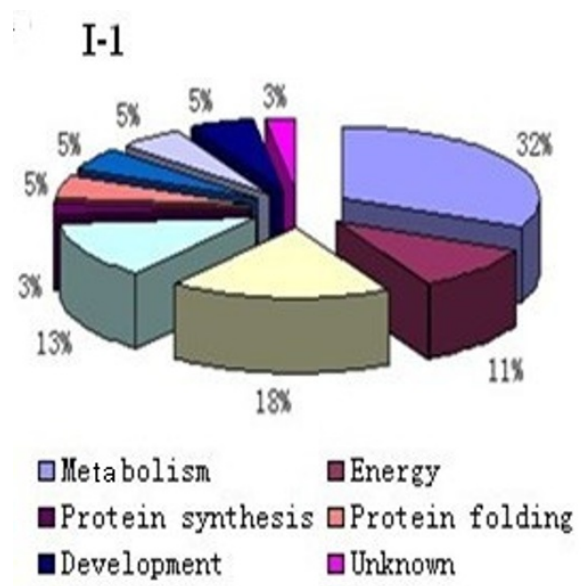

I-2

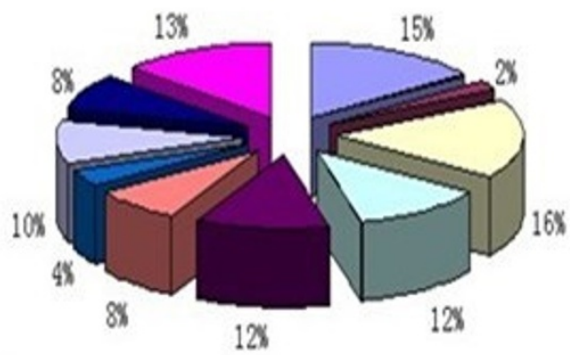

$\begin{array}{ll}\square \text { Photosynthesis } & \text { QTranscription } \\ \square \text { Transport } & \text { aStress }\end{array}$

Figure 5 Pie charts classifying the identified I-1 and I-2 proteins according to biological function. The identified proteins were grouped according to their biological processes and are expressed in percentage.

ATP synthase (spots 156 and 152) were identified for I-1, whereas only the ATP synthase $\beta$-subunit was detected in the I- 2 proteome. ATP synthase is a very large complex $(>500 \mathrm{kDa})$ embedded in the inner membranes of chloroplasts and mitochondria. It utilizes the products of fat and carbohydrate breakdown to generate proton gradients across membranes, which then drive ATP synthesis.

\section{Proteins involved in photosynthesis}

Photosynthesis uses light energy and chlorophyll to synthesize simple sugars from carbon dioxide and water and to capture the energy as phosphate bonds in ATP. ATP is then available as an energy source, and the sugars are used as building blocks to produce other cell structural and storage components. Photosynthetic enzymes including RuBisCo (spots 2, 37, 46, and 33), oxygen-evolving enhancer protein 1 (spots 126 and 90),

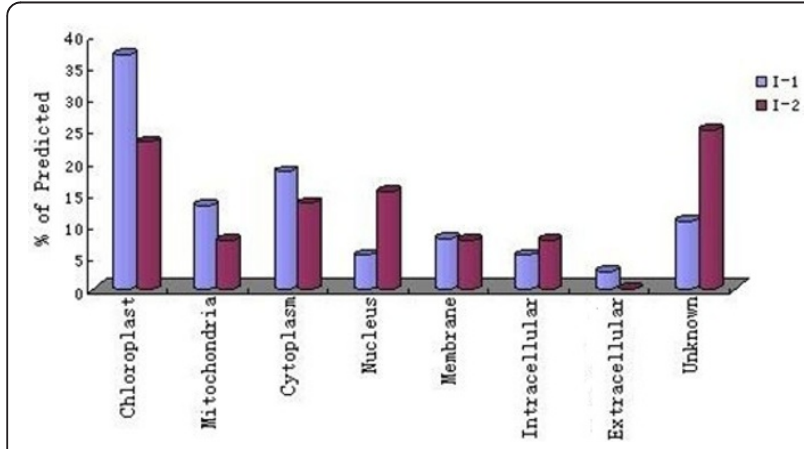

Figure 6 Gene ontology classification of identified I-1 and I-2 proteins according to their subcellular location. Subcellular locations of the proteins were assigned according to the GO annotations and are expressed as percentages of the assigned proteins. and triosephosphate isomerase (spots 69, 72, and 82) were found in the I-1 and I-2 proteomes.

Interestingly, many other proteins involved in sugar synthesis were found only in the I-2 proteome, i.e., alpha, alpha-trehalose-phosphate synthase (UDP-forming, spot 17), granule-bound starch synthase 1 (spot 35), and ribulose-phosphate 3-epimerase (spot 64). Alpha, alpha-trehalose-phosphate synthase (UDP-forming) synthesizes alpha, alpha-trehalose 6-phosphate from D-glucose 6-phosphate, and is then dephosphorylated to trehalose by trehalose 6-phosphate phosphatase. Trehalose metabolism, a side-branch of carbon flux in bacteria, yeast, and plants, has recently drawn attention because it may partially regulate plant growth, development, and stress resistance [44]. Granule-bound starch synthase 1 is required for the synthesis of amylase, and ribulose-phosphate 3-epimerase (pentose-5-phosphate 3-epimerase) converts d-ribulose 5 -phosphate into d-xylulose 5-phosphate as part of the reductive pentose phosphate (Calvin) cycle. These aforementioned enzymes are very important for sugar synthesis. Sugars can act as signaling molecules in microorganisms, animals, and plants. During plant growth and development, sugars modulate seed germination, seedling development, root and leaf differentiation, floral transition, fruit ripening, embryogenesis, senescence, and responses to light, stress, and pathogens [45-53]. For strawberries, the clonal plant is usually found at the second node, so the identification of specific sugar-related enzymes found only in the I-2 proteome should increase our understanding of the different internodal developmental mechanisms. Our results indicate that positive interactions between sugar synthesis and hormonal signaling in I-2 may be necessary for asexual strawberry reproduction. 


\section{Proteins involved in protein synthesis}

We identified only one I-1 protein associated with protein synthesis, namely the $50 \mathrm{~S}$ ribosomal protein L33 (spot 154). Cell growth and division require the synthesis of new proteins and ribosomes. L33 is involved in the biogenesis of both the small and large ribosomal subunits. For I-2, we found the eukaryotic translation initiation factor $5 \mathrm{~A}$ (spots 28 and 37 ), which is a highly conserved eukaryotic protein. Eukaryotic translation initiation factor $5 \mathrm{~A}$ appears to be involved in RNA metabolism and trafficking in mammals and yeast, thus regulating cell proliferation, cell growth, and programmed cell death [54]. In plants, however, its physiological function is not known.

\section{Proteins involved in protein folding and protein degradation}

For I-1, two proteins involved in protein folding and processing were identified, and for I-2, four proteins involved in protein modification and degradation were found. The heat shock protein 81-3 (spot 45) found in the I-1 proteome is a molecular chaperone and likely involved in signal transduction and development associated with certain hormone receptors and kinases [55]. Interestingly, three of the I-2 proteins, anaphase-promoting complex subunit 2 (APC2; spot 148), U-box domain-containing protein 34 (spots 153 and 175), and ubiquitin carboxyl-terminal hydrolase 6 (spot 171), are all ubiquitin-dependent proteins involved in catabolism. The ubiquitin-proteasome pathway is responsible in large part for protein degradation and consequently regulates many aspects of development. The identification of the aforementioned proteins suggests that research on the ubiquitin conjugation pathway might illuminate the mechanism of I-2 clonal multiplication.

\section{Proteins involved in transcription}

We identified five I-1 proteins, histone acetyltransferase GCN5 (spot 6), transcription factor bHLH145 (spot 27), DNA polymerase (spot 136), pentatricopeptide repeatcontaining protein (spot 18), and DNA-directed RNA polymerase (spot 92), that are involved in transcription. GCN5 is a coactivator of transcriptional regulation $[56,57]$. The I-2 homeodomain-leucine zipper protein (spot 18) is a putative transcription factor required for correct morphological development and maturation of trichomes as well as for normal development of seed coat mucilage [58]. The function of histone regulator protein (spots 47 and 168) has yet to be determined; however, it may be involved in maintining knox genes silencing throughout leaf development [59]. The twocomponent response regulator (spot 121) is involved in the His-to-Asp phosphorelay signal transduction system [60].
Proteins involved in stress response and development

Twelve of the identified I-1 and I-2 proteins are associated with stress and development. One I-1 protein (spots 62 and 151) and five I-2 proteins (e.g., spots 4, 9, 20,41 , and 154) are involved in stress responses, and two I-1 proteins (spots 53 and 81) and four I-2 proteins (spots 2, 11, 38, and 68) are associated with development. Spot 53 is 3-ketoacyl-CoA synthase, which mediates the synthesis of very long chain fatty acids (26 to 30 carbons). Spot 81 is the cytoplasmic dynein 2 heavy chain1, which is an intracellular motor for retrograde vesicle and organelle motility along microtubules.

For I-2, monodehydroascorbate reductase (spots 41 and 154) was identified and is an oxidoreductase that oxidizes NADH or NADPH using a quinone as the oxidant during the glutathione-ascorbate cycle, a major plant antioxidant system that protects against reactive oxygen species. Monodehydroascorbate reductase activity has been found in chloroplasts, the cytosol, mitochondria, glyoxysomes, and leaf peroxisomes [61]. 1aminocyclopropane-1-carboxylate synthase 7 (spot 68) catalyzes the conversion of AdoMet into 1-aminocyclopropane-1-carboxylate, a precursor of ethylene.

\section{Comparison of metabolic pathways in I-1 and I-2}

Interestingly, many of the proteins involved in central metabolic pathways (e.g., glycolysis, the citric acid cycle, pyruvate metabolism) were identified in both the I-1 and I-2 proteomes. Using the KEGG PATHWAY database (http://www.genome.jp/kegg/pathway.html), we classified more of the I-1 proteins than the I- 2 proteins as involved in carbon fixation, glyoxylate and dicarboxylate metabolism, glycolysis/gluconeogenesis, and oxidative phosphorylation (Figure 7). For the two internodes, seven enzymes (15 spots) were classified as carbon fixing, and $13.2 \%$ of the I- 1 proteins belonged to this category, whereas only $7.7 \%$ of those from I- 2 did. The difference is related to the number of spots found for the RuBisCo complex, i.e., more were found for I- 1 than for I-2. Most of the enzymes of the citrate cycle, pyruvate metabolism, fructose and mannose metabolism, and starch and sucrose metabolism were identified in the two proteomes, and the numbers of proteins found for each pathway were similar, suggesting that the housekeeping pathways are needed for stolon viability. Many enzymes involved in the ubiquitin-proteasome pathway were also identified but were greater in relative number in the I-2 proteome (Figure 7). In plants, regulated protein degradation by the ubiquitin-proteasome system contributes substantially to development by affecting many processes, e.g., embryogenesis, hormone signaling, and senescence, which suggests that the ubiquitin-proteasome system may play a central role in I-2 morphogenesis. The I-1 and I- 2 proteomes, which we have 


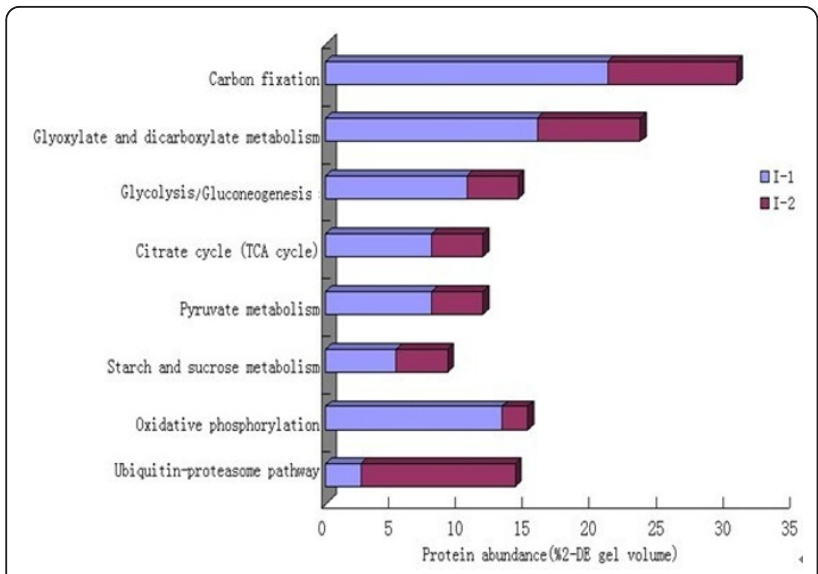

Figure 7 Protein abundance for nine metabolic pathways in I-1 and $\mathbf{I - 2}$. For carbon fixation, glyoxylate and dicarboxylate metabolism, glycolysis/gluconeogenesis, pentose phosphate pathway, pyruvate metabolism, starch and sucrose metabolism, oxidative phosphorylation, ubiquitin-proteasome pathway; 7, 6, 4, 1, $1,3,6$, and 5 enzymes were identified, respectively, corresponding to $15,10,6,5,5,4,6$, and 62 -DE spots.

described herein, will allow us to analyze and compare proteins in metabolic pathways and may provide new insights into the regulation and expression of various molecular networks.

\section{Possible PPI networks and adventitious root-formation mechanisms in $\mathrm{I}-2$}

Proteins are the main catalysts, structural elements, signaling messengers, and molecular machines of biological

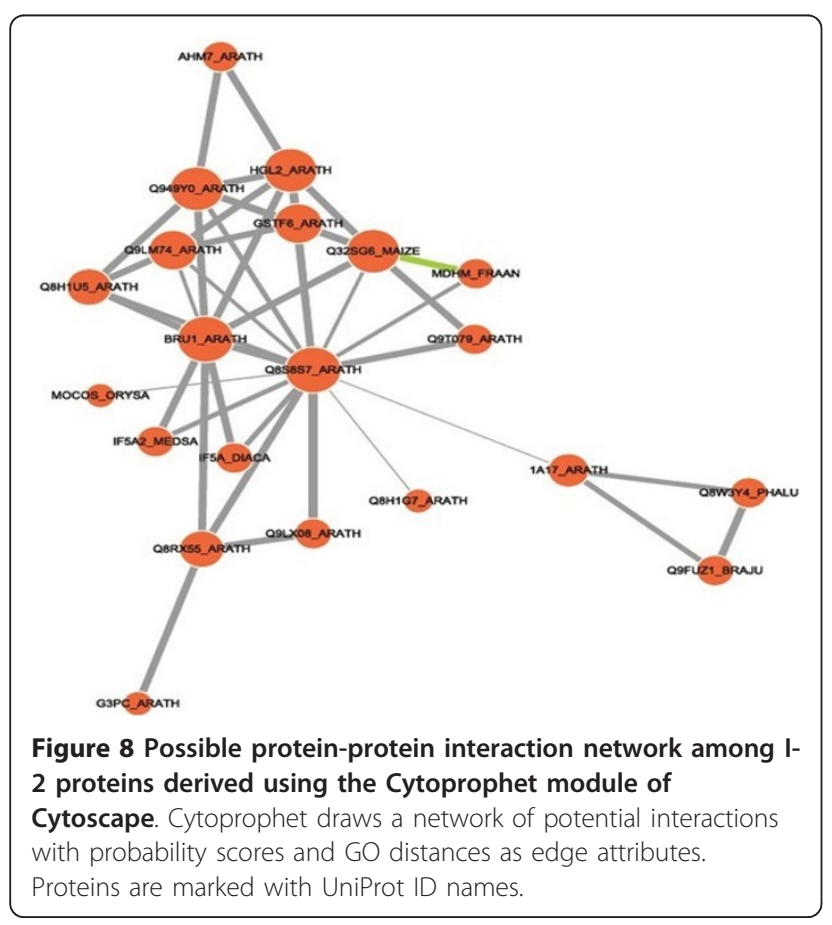

tissues [62]. PPIs are extremely important in orchestrating cellular events. Protein interaction networks provide road maps of cellular pathways. Therefore, many methods are used to characterize PPIs, which include physical interactions and functional linkages [63].

Although we could not use Cytoprophet to delineate a PPI network for I-1 because of limited information, a possible PPI network was found for I-2 (Figure 8). U-box domain-containing protein 34 (PUB34) (Q8S8S7_ARATH) is the central core protein of the signaling network, as it interacts with many other proteins, e.g., alpha, alpha-trehalose-phosphate synthase (TPS4) (Q9T079_ARATH), APC2 (Q8H1U5_ARATH), 1-aminocyclopropane-1-carboxylate synthase 7 (ACS7) (1A17_ ARATH), and EIF5A. APC2 is an E3 ubiquitin ligase that is a component of the SCF family ubiquitin ligases, which catalyze the attachment of ubiquitin to the lysine side chains of securin and mitotic cyclins [64-66]. EIF5A interacts with BRUSHY1 (BRU1_ARATH), which is required for the proper arrangement of cells in the root and shoot apical meristems. Ubiquitin-mediated protein degradation probably affects meristem structural formation by modulating the concentration of cell-cycle regulators and transcription factors [67]. Therefore, the ubiquitin system may be vital during the morphogenesis of clonal plants.

Adventitious roots develop from the second node at the end of I-2 before clonal plant formation. We developed a model for adventitious root formation in I-2 based on published data [64-69] and our findings; the model includes four regulated pathways (Figure 9). Regulated protein degradation has repeatedly been identified as a key component of cell-cycle regulation. Securin inhibits a protease called separase, which cleaves cohesins allowing anaphase onset. Activated $\mathrm{APC}^{\mathrm{cdc} 20}$ targets securin for degradation, which initiates the metaphase-to-anaphase transition [68]. In addition, biochemical and molecular studies have shown that EIF-5A is crucial for plant growth and development as it regulates cell division and cell growth [69]. Continuous cell division, elongation, and differentiation can cause the formation of root primordia, so the APC complex-related and EIF-5A-related biological processes may be two important pathways that regulate the formation of adventitious roots. Moreover, ACS7 catalyzes the conversion of AdoMet into 1-aminocyclopropane-1-carboxylate, a direct precursor of ethylene, whereas ACS7 is ubiquitinated. Ubiquitination probably leads to its subsequent degradation, thus controlling ethylene production. Ethylene can regulate root initiation and emergence. Conversely, as an important catalytic enzyme, TPS4 plays a central role in the complex signaling network that links sugars and hormones with its interacting partner PUB34. Together, the four pathways work synergistically to induce formation of adventitious roots. 


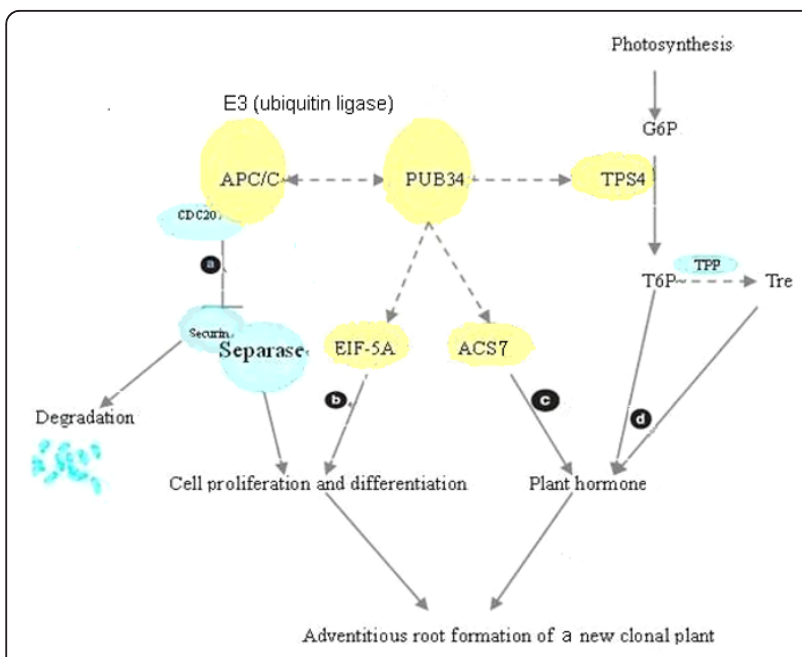

Figure 9 Model for adventitious root and clonal plant formation in I-2 that incorporates four regulated pathways.

Five identified $1-2$ proteins were integrated into the model, and the possible PPls are shown (dashed lines) based on the PPI network in Figure 8. (a) Anaphase-promoting complex (APC/C) is a ubiquitin ligase that plays a key role in the cell cycle. (b) Eukaryotic translation initiation factor 5A (EIF-5A) may interact with PUB34 to regulate cell division. (c) ACS7, when interacting with ubiquitin ligase, plays a central role in ethylene biosynthesis. (d) Important regulatory effects on plant growth and development have been reported for trehalose (Tre) and trehalose 6-phosphate (T6P). (CDC20: cell-division cycle protein 20; G6P: glucose 6-phosphate; TPP: trehalose-6phosphate phosphatase

\section{Conclusions}

For this research, we compared the proteomes of the I-1 and I-2 internodes of the strawberry stolon to begin to elucidate the how the differences in the proteomes affect the growth and functional characteristics of the two internodes as only the second node, at the end of I-2, tends to form adventitious roots and a clonal plant. In I1 , the majority of the proteins were involved in metabolism, photosynthesis, energy, and transcription. In I-2, relatively more proteins were involved in photosynthesis, carbohydrate metabolism, stress responses, and protein folding and degradation, indicating that these many different processes work synergistically to induce cell differentiation necessary for root and plant formation. Given our findings and those of others, we present a scheme for protein interactions that could be responsible for adventitious root and clonal plant formation in I-2.

\section{Acknowledgements}

This research was supported in part by the Key Scientific and Technological Innovation Projects of Hangzhou (Grant No. 20072312A03 to Songlin Ruan).

\section{Author details}

'Laboratory of Plant Molecular Biology and Proteomics, Institute of Biology, Hangzhou Academy of Agricultural Sciences, Hangzhou 310024, China.
${ }^{2}$ School of Life Science, Zhejiang Chinese Medical University, Hangzhou 310053, China.

\section{Authors' contributions}

XF designed and carried out experiments, analyzed data, and wrote the manuscript. HM designed the study, interpreted data, and assisted with the writing of the manuscript. DL did most of the MS analysis and assisted with the evaluation of MS data. HY conceived the study and participated in its design. WL designed and analyzed experiments. SR conceived of, designed, and coordinated the study, and assisted with the writing of the manuscript. All authors read and approved the final manuscript.

\section{Competing interests}

The authors declare that they have no competing interests.

Received: 21 January 2011 Accepted: 14 May 2011

Published: 14 May 2011

\section{References}

1. Stuefer JF: Separating the effects of assimilate and water integration in clonal fragments by the use of steam-girdling. Abstr Bot 1995, 19:75-81.

2. Stuefer $\mathrm{JF}$, Huber $\mathrm{H}$ : The role of stolon internodes for ramet survival after clone fragmentation in potentilla anserina. Ecol Lett 1999, 2:135-139.

3. Alonso-Blanco C, Mendez-Vigo B, Koornneef M: From phenotypic to molecular polymorphisms involved in naturally occurring variation of plant development. Int J Dev Biol 2005, 49:717-732.

4. Jorrín JD, Rubiales E, Dumas-Gaudot AM, Maldonado M, Castillejo A, Curto M: Proteomics: a promising approach to study biotic interaction in legumes. A review. Euphytica 2006, 147:37-47.

5. Bianco L, Lopez L, Scalone AG, Carli MD, Desiderio A, Benvenuto E, Perrotta G: Strawberry proteome characterization and its regulation during fruit ripening and in different genotypes. J Proteomics 2009, 72:586-607.

6. Giavalisco P, Nordhoff E, Kreitler T, Klöppel KD, Lehrach H, Klose J, Gobom J: Proteome analysis of Arabidopsis thaliana by two-dimensional gel electrophoresis and matrix-assisted laser desorption/ionisation-time of flight mass spectrometry. Proteomics 2005, 5:1902-1913.

7. Larrainzar E, Wienkoop S, Wolfram W, Rubén L, Cesar Al, González EM: Medicago truncatula root nodule proteome analysis reveals differential plant and bacteroid responses to drought stress. Plant Physiol 2007, 144:1495-1507.

8. Hjerno K, Alm R, Canback B, Matthiesen R, Trajkovski K, Bjork L, Roepstorff P, Emanuelsson CS: Down-regulation of the strawberry Bet v 1-homologous allergen in concert with the flavonoid biosynthesis pathway in colourless strawberry mutant. Proteomics 2006, 6(Suppl 5):1574-1587.

9. Takashi $\mathrm{N}$, Yutaka $\mathrm{H}$ : Elongation of strawberry runners in relation to length and number of cells. J Agricultural Res 1993, 43:3-4.

10. Bradford MM: A rapid and sensitive method for quantitation of microgram quantities of protein utilizing the principle of protein-dye binding. Anal Biochem 1976, 72:248-254.

11. Wheeler CH, Dunn MJ, Rheumatology H, London UK, Pharmacia A: A modified silver staining protocol for visualization of proteins compatible with matrix-assisted laser desorption/ionization and electrospray ionization-mass spectrometry. Electrophoresis 2000, 21:3666-3672.

12. Mechin V, Balliau T, Chateau-Joubert S, Davanture M: A two-dimensional proteome map of maize endosperm. Phytochemistry 2004, 65:1609-1618.

13. Giavalisco $P$, Nordhoff $E$, Kreitler T, Kloppel KD: Proteome analysis of Arabidopsis thaliana by two-dimensional gel electrophoresis and matrixassisted laser desorption/ionisation-time of flight mass spectrometry. Proteomics 2005, 5:1902-1913.

14. Jiang Y, Yang B, Harris NS, Deyholos MK: Comparative proteomic analysis of $\mathrm{NaCl}$ stress-responsive proteins in Arabidopsis roots. J Exp Bot 2007, 58:3591-3607.

15. Ishikawa T, Yoshimura K, Tamoi M, Takeda T, Shigeoka S: Alternative mRNA splicing of 3 '-terminal exons generates ascorbate peroxidase isoenzymes in spinach (Spinacia oleracea) chloroplasts. J Biochem 1997, 328(Suppl 3):795-800.

16. Holmes-Davis R, Tanaka CK, Vensel WH, Hurkman WJ, McCormick S: Proteome mapping of mature pollen of Arabidopsis thaliana. Proteomics 2005, 5(Suppl 18):4864-4884. 
17. Ndimba BK, Chivasa S, Simon WJ, Slabas AR: Identification of Arabidopsis salt and osmotic stress responsive proteins using two-dimensional difference gel electrophoresis and mass spectrometry. Proteomics 2005, 5(Suppl 16):4185-4196.

18. Huber SC, Hardin SC: Numerous post translational modifications provide opportunities for the intricate regulation of metabolic enzymes at multiple levels. Curr opin Plant Biol 2004, 7:318-322.

19. Hoffmann R, Valencia A: A gene network for navigating the literature. Nat Genet 2004, 36:664.

20. Mechin V, Balliau T, Chateau-Joubert S, Davanture M, Langella O, Négroni L, Prioul JL, Thévenot C, Zivy M, Damerval M: A two-dimensional proteome map of maize endosperm. Phytochemistry 2004, 65:1609-1618.

21. Koller A, Washburn MP, Lange BM, Andon NL, Deciu C, Haynes PA, Hays L, Schieltz D, Ulaszek R, Wei J, Wolters D, John R, Yates JR: Proteomic survey of metabolic pathways in rice. Proc Natl Acad Sci USA 2002, 18:11969-11974

22. Hajduch M, Casteel JE, Hurrelmeyer KE, Song Z, Agrawal GK, Thelen JJ: Proteomic analysis of seed filling in Brassica napus. developmental characterization of metabolic isozymes using high resolution twodimensional gel electrophoresis. Plant Physiol 2006, 141:32-46.

23. Cocco L, Manzoli L, Barnabei O, Martelli AM: Significance of subnuclear localization of key players of inositol lipid cycle. Adv Enzyme Regul 2004, 44:51-60.

24. Itoh K, Brott BK, Bae GU, Ratcliffe MJ, Sokol SY: Nuclear localization is required for dishevelled function in wnt/beta-catenin signaling. $J$ Biol 2005, 4(Suppl 1):3.

25. Chou K, Cai Y: Prediction of protein subcellular locations by GO-FunDPseAA predictor. Biochem Biophys Res Commun 2004, 320:1236-1239.

26. Lei Z, Dai Y: Assessing protein similarity with gene ontology and its use in subnuclear localization prediction. BMC Bioinf 2006, 7:491.

27. Blum T, Briesemeister S, Kohlbacher O: MultiLoc2: integrating phylogeny and gene ontology terms improves subcellular protein localization prediction. BMC Bioinf 2009, 10:274

28. Briesemeister S, Blum T, Brady S: SherLoc2: a high-accuracy hybrid method for predicting subcellular localization of proteins. J Proteome Res 2009, 8:5363-5366.

29. Huang WL, Tung CW, Ho SW: ProLoc-GO: utilizing informative gene ontology terms for sequence-based prediction of protein subcellular localization. BMC Bioinf 2008, 9:80.

30. Van Wijk K: Challenges and prospects of plant proteomics. Plant Physiol 2001, 126:501-508

31. Brick DJ, Brumlik MJ, Buckley JT, Cao JX, Davies PC, Misra S, Tranbarger TJ, Upton C: A new family of lipolytic plant enzymes with members in rice, arabidopsis and maize. FEBS Lett 1995, 377:475-480.

32. Abeles FB, Bosshart RP, Forrence LE, Habig WH: Preparation and purification of glucanase and chitinase from bean leaves. Plant Physiol 1970, 47:129-134.

33. Odanaka S, Bennett AB, Kanayama Y: Distinct physiological roles of fructokinase isozymes revealed by gene-specific suppression of Frk1 and Frk2 expression in tomato. Plant Physiol 2002, 20:703-706.

34. Catoni GL: S-Adenosylmethionine: a new intermediate formed enzymatically from L-methionine and adenosinetriphosphate. J Biol Chem 1953, 204(suppl 1):403-416.

35. Chiang PK, Gordon RK, Tal J, Zeng GC, Doctor BP: Pardhasaradhi K. McCann PP: S-Adenosylmethionine and methylation. FASEB J 1996, 10(suppl 4):471-480.

36. Shimizu Y, Gupta S, Masuda K, Maranda L, Walker CK, Wang R: Dinoflagellate and other microalgal toxins: chemistry and biochemistry. Pure Appl Chem 1989, 61(Suppl 3):513-516.

37. Shimizu Y: Microalgal metabolites: a new perspective. Annu Rev Microbiol 1996, 50:431-465.

38. Tabor H, Rosenthal SM, Tabor CW: The biosynthesis of spermidine and spermine from putrescine and methionine. J Biol Chem 1958, 233(Suppl 4):907-914.

39. Chan KL, New D, Ghandhi S, Wong F, Lam CM, Wong JT: Transcript levels of the eukaryotic translation initiation factor $5 \mathrm{~A}$ gene peak at early $\mathrm{G}(1)$ phase of the cell cycle in the dinoflagellate Crypthecodinium cohnii. Appl Environ Microbiol 2002, 68(Suppl 5):2278-2284.

40. Yang S, Hoffman N: Ethylene biosynthesis and its regulation in higher plants. Annu Rev Plant Physiol 1984, 35:155-189.
41. Kutchan TM: Alkaloid biosynthesis-the basis for metabolic engineering of medicinal plants. Plant Cell 1995, 7(Suppl 7):1059-1070.

42. Slapeta J, Stejskal F, Keithly JS: Characterization of S-adenosylmethionine synthetase in Cryptosporidium parvum (Apicomplexa). FEMS Microbiol Lett 2003, 225(Suppl 2):271-277.

43. Brejning J, Jespersen L: Protein expression during lag phase and growth initiation in Saccharomyces cerevisiae. Int J Food Microbiol 2002, 75(Suppl 1-2):27-38.

44. Rolland F, Winderickx J, Johan M: Glucose-sensing mechanisms in eukaryotic cells. Trends Biochem Sci 2001, 26:310-317.

45. Koch KE: Carbohydrate modulated gene expression in plants. Annu Rev Plant Physiol Plant Mol Biol 1996, 47:509-540.

46. Roitsch T: Source-sink regulation by sugar and stress. Curr Opin Plant Biol 1999, 2:198-206.

47. Sheen J, Zhou L, Jang JC: Sugars as signaling molecules. Curr Opin Plant Biol 1999, 2:410-418.

48. Wobus $\mathrm{U}$, Weber $\mathrm{H}$ : Sugars as signal molecules in plant seed development. Biol Chem 1999, 380:937-944.

49. Smeekens S: Sugar-induced signal transduction in plants. Annu Rev Plant Physiol Plant Mol Biol 2000, 51:49-81.

50. Xiao W, Sheen J, Jang JC: The role of hexokinase in plant sugar signal transduction and growth and development. Plant Mol Biol 2000, 44:451-461.

51. Coruzzi GM, Zhou L: Carbon and nitrogen sensing and signaling in plants: emerging matrix effects. Curr Opin Plant Biol 2001, 4:247-253.

52. Ohto M, Onai K, Furukawa Y, Aoki E: Effects of sugar on vegetative development and floral transition in Arabidopsis. Plant Physiol 2001, 127:252-261.

53. Corbesier $\mathrm{L}$, Bernier G, Perilleux C: C:N ratio increases in the phloem sap during floral transition of the long-day plants Sinapis alba and Arabidopsis thaliana. Plant Cell Physiol 2002, 43:684-88.

54. Kang HA, Schwelberger HG, Hershey JW: Translation initiation factor elF$5 \mathrm{~A}$, the hypusine-containing protein, is phosphorylated on serine in Saccharomyces cerevisiae. J Biol Chem 1993, 268:14750-14756.

55. Saracco SA, Hansson M, Scalf M, Walker JM, Smith LM, Vierstra RD: Tandem affinity purification and mass spectrometric analysis of ubiquitylated proteins in Arabidopsis. J Plant 2009, 59:344-358.

56. Brownell JE, Zhou J, Ranalli T, Kobayashi R, Edmondson DG, Roth SY, Allis CD: Tetrahymena histone acetyltransferase A: a homolog to yeast Gcn5p linking histone acetylation to gene activation. Cell 1996, 84(Suppl 6):843-851.

57. Lee TI, Young RA: Transcription of eukaryotic protein-coding genes. Annu Rev Genet 2000, 34:77-137.

58. Ohashi Y, Oka A, Ruberti I, Morelli G, Aoyama T: Entopically additive expression of GLABRA2 alters the frequency and spacing of trichome initiation. J Plant 2002, 29:359-369.

59. Phelps-Durr TL, Thomas J, Vahab P, Timmermans MCP: Maize rough sheath2 and its Arabidopsis orthologue ASYMMETRIC LEAVES1 interact with HIRA, a predicted histone chaperone, to maintain knox gene silencing and determinacy during organogenesis. Plant Cell 2005, 17:2886-2898.

60. To JPC, Haberer G, Ferreira FJ, Deruere J, Mason MG, Schaller GE, Alonso JM, Ecker JR, Kieber JJ: Type-A Arabidopsis response regulators are partially redundant negative regulators of cytokinin signaling. Plant Cell 2004, 16:658-671.

61. Leterrier M, Corpas F, Barroso J, Sandalio L: Peroxisomal monodehydroascorbate reductase. Genomic clone characterization and functional analysis under environmental stress conditions. Plant Physiol 2005, 138(Suppl 4):2111-2123.

62. Eisenberg D, Marcotte EM, Xenarios I, Yeates TO: Protein function in the post-genomic era. Nature 2000, 405(6788):823-826.

63. Assenov Y, Ramírez F, Schelhorn SE, Lengauer T, Albrecht M: Computing topological parameters of biological networks. Bioinformatics 2008, 24(Suppl 2):282-284.

64. King RW, Peters JM, Tugendreich S, Rolfe M, Hieter P, Kirschner MW: A $20 \mathrm{~S}$ complex containing CDC27 and CDC16 catalyzes the mitosis-specific conjugation of ubiquitin to cyclin B. Cell 1995, 81:279-288.

65. Aristarkhov A, Eytan E, Moghe A, Admon A, Hershko A, Ruderman JV: E2-C, a cyclin-selectiveubiquitin carrier protein required for the destruction of mitotic cyclins. Proc Natl Acad Sci 1996, 93:4294-4299. 
66. Yu H, King RW, Peters JM, Kirschner MW: Identification of a novel ubiquitin-conjugating enzyme involved in mitotic cyclin degradation. Curr Biol 1996, 6:455-466.

67. Vernoux T, Autran D, Traas J: Developmental control of cell division patterns in the shoot apex. Plant Mol Biol 2000, 43:569-581.

68. Holt $\sqcup$, Krutchinsky AN, Morgan DO: Positive feedback sharpens the anaphase switch. Nature 2008, 454(Suppl 7202):353-7.

69. Haizhong F, Qingguo C, Jian F, Jian Z, Xiaohui Y, Jianru Z: Functional characterization of the Arabidopsis eukaryotic translation initiation factor 5A-2 that Plays a crucial role in plant growth and development by regulating cell division, cell growth, and cell death. Plant Physiology 2007, 144:1531-1545.

doi:10.1186/1477-5956-9-26

Cite this article as: Fang et al:: Comparative proteomics analysis of proteins expressed in the $\mathrm{I}-1$ and $\mathrm{I}-2$ internodes of strawberry stolons. Proteome Science 2011 9:26.

\section{Submit your next manuscript to BioMed Central} and take full advantage of:

- Convenient online submission

- Thorough peer review

- No space constraints or color figure charges

- Immediate publication on acceptance

- Inclusion in PubMed, CAS, Scopus and Google Scholar

- Research which is freely available for redistribution

Submit your manuscript at www.biomedcentral.com/submit
( Biomed Central 